\title{
The Press and Libel Before New York Times v. Sullivan
}

\author{
Samantha Barbas*
}

\section{TABLE OF CONTENTS}

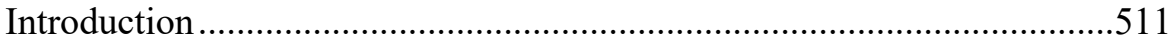

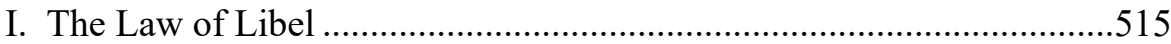

II. The Press and Libel, 1880-1920 _..........................................................517

A. Libel and the Rise of the Commercial Press............................517

B. Publishers' Response ...........................................................520

C. "Libel Vetting" and the Professionalization of Journalism ......522

1. The Professionalization of Journalism ...............................522

2. "Libel Avoidance" ............................................................524

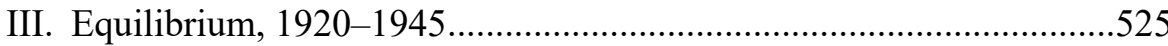

A. The Libel Prevention and Defense System ............................527

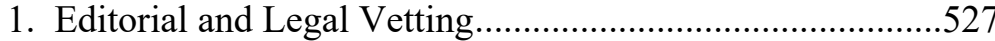

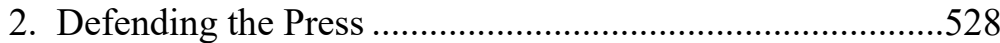

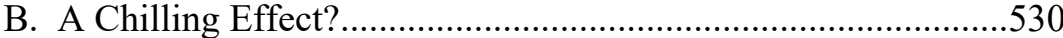

C. The "Libel Climate" of the 1930s and '40s..............................532

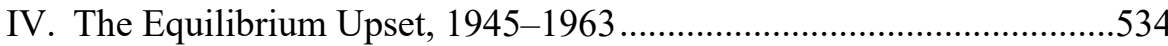

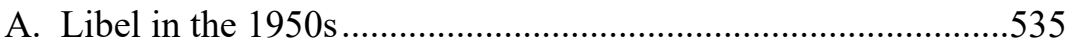

B. The New Libel Crisis................................................................538

C. New York Times v. Sullivan …………....................................541

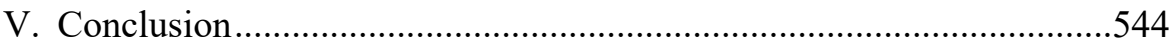

\section{INTRODUCTION}

The Supreme Court's decision in the landmark 1964 case New York Times $v$. Sullivan was one of the most significant First Amendment decisions in history. In Sullivan, the Court constitutionalized the law of libel and instituted strong protections for the press in its reporting on public officials. A unanimous Court held that, in

* Professor of Law, University of Buffalo School of Law; J.D., Stanford Law School; Ph.D., History, University of California, Berkeley.

(C) 2021 Barbas. This is an open access article distributed under the terms of the Creative Commons Attribution License, which permits unrestricted use, distribution, and reproduction, provided the original author and source are credited. 
order for a public official to recover in a libel suit, the official must demonstrate, as a First Amendment requirement, that the statement about him or her was false and made with "actual malice," meaning that the statement was made "with knowledge that it was false or with reckless disregard of whether it was false or not." Sullivan ended the centuries-old common law rule of strict liability in libel cases and the presumption of falsity that placed the burden on defendants to prove the truth of the alleged defamatory statement. The suit had been brought by L.B. Sullivan, City Commissioner of Montgomery, Alabama, over an advertisement in the Times, sponsored by a civil rights group, that accused Southern officials of brutality against civil rights protesters, and in so doing allegedly defamed Sullivan. ${ }^{2}$ The lawsuit was one of several brought by Southern officials against the Times in the hopes of halting sympathetic coverage of the civil rights movement. ${ }^{3}$

Scholars have suggested that a primary reason the Court took the case and instituted sweeping protections for the press in libel law was to protect the ability of the media to report on the civil rights movement, and thus to generate Northern support for civil rights legislation and desegregation efforts. ${ }^{4}$ In a well-known article published shortly after the decision, First Amendment scholar Harry Kalven Jr. observed the connection between Sullivan and the Warren Court's sympathies towards the civil rights movement. ${ }^{5}$ Legal historians Melvin Urofsky and Kermit Hall, in a book-length study of the case, made similar claims. ${ }^{6}$ One legal scholar has written that Sullivan was the "paradigmatic example of Warren Court First Amendment jurisprudence in service of the civil rights cause."7

1. N.Y. Times Co. v. Sullivan, 376 U.S. 254, 280-83 (1964).

2. Id. at $256-57$.

3. Bruce L. Ottley, John Bruce Lewis \& Younghee Jin Ottley, New York Times v. Sullivan: $A$ Retrospective Examination, 33 DEPAUL L. REV. 741, 748-49 (1984); ANTHONY LEWIS, MAKE NO LAW: The Sullivan CASE And THE First Amendment 42 (1991); Kermit Hall, New York Times v. Sullivan: The Case and Its Times, Keynote Address at the First Annual Symposium of the Constitutional Law Resource Center (Mar. 30 and 31, 1990), in DRAKE L. REV. 21, 31 (1990) (special edition outside regular volume numbering).

4. See, e.g., Burt Neuborne, The Gravitational Pull of Race on the Warren Court, 2010 SUP. CT. ReV. 59, 79 (2010); Paul Horwitz, Institutional Actors in New York Times Co. v. Sullivan, 48 GA. L. REV. 809, 821 (2014) ("The press was not the only major institution involved in Sullivan. The other prime target of Sullivan and the other plaintiffs was the Civil Rights Movement itself."); Christopher W. Schmidt, New York Times v. Sullivan and the Legal Attack on the Civil Rights Movement, 66 ALA. L. REv. 293 (2014); Melvin I. Urofsky, New York Times Co. v. Sullivan as a Civil Rights Case, 19 Comm. L. \& POL'Y 157 (2014); Fred D. Gray, The Sullivan Case: A Direct Product of the Civil Rights Movement, 42 CAS. W. Res. L. ReV. 1223 (1992); Carlo A. Pedrioli, New York Times v. Sullivan and the Rhetorics of Race: A Look at the Briefs, Oral Arguments, Opinions, 7 GeO. J. L. \& Mod. Critical RaCe PersP. 109 (2015).

5. Harry Kalven Jr., The New York Times Case: A Note on the Central Meaning of the First Amendment, 1964 Sup. CT. REV. 191, 192 (1964).

6. See generally Kermit L. Hall \& Melvin I. URofsky, NeW YorK Times V. SulliVAN: CiviL Rights, LIBEL LAW, AND THE FREE PRESS (2011).

7. Lillian R. BeVier, Intersection and Divergence: Some Reflections on the Warren Court, Civil Rights, and the First Amendment, 59 WASH. \& LEE L. REV. 1075, 1080 (2002); see also id. at 1075 ("[T]he Court protected the civil liberties of free speech and association to promote the civil right of racial equality."). 
This Article argues that Sullivan was not only a "civil rights case," but also very much a libel case, one that was influenced by contemporaneous debates over libel law and freedom of the press. The Court intervened in what was perceived at the time as a near-crisis for the press caused by an increasing number of libel suits and large damage awards against publishers in the 1950s and '60s. This escalation was a notable departure from the relatively tame "libel climate" of the previous forty years. ${ }^{8}$ For most of the first half of the twentieth century, the press had been able, to a remarkable degree, to avoid and defeat libel suits through strategic navigation of the libel law landscape. By combining a tactical accommodation of libel law with a dedicated resistance to it, the press had learned to "liv[e] with the law of libel."" By the 1940s, most of the nation's major newspapers faced only a handful of libel suits each year, and the amount paid in judgments and settlements was low. The upset of that equilibrium, starting in the 1950s, put libel on the Supreme Court's radar, and it spurred the Court to contemplate more aggressive intervention into the state law of libel.

In what follows, I shed new light on Sullivan through an account of the history of libel law and litigation in the United States in the years prior to the case, and the libel law context in which Sullivan was initiated and rose through the courts. This Article does not dwell on the constitutional law developments that influenced Sullivan or the common law of libel prior to Sullivan, but instead focuses on how the press dealt with libel, and the practical implications of libel law for American print media in the years leading up to Sullivan. In so doing, it reveals a reality about libel law that cannot be readily gleaned from a study of case law or treatises: that for much of the twentieth century, especially prior to the 1950 s, libel did affect press behavior and the ability of the press to publish newsworthy stories, although it likely did not have the highly chilling effect on the press that its rigid formal doctrines suggested. Libel law did impose burdens on the press; it did require self-censoring to some extent. Yet many sectors of the press enjoyed broad latitude to report the news and to comment on politics and public issues, libel law notwithstanding.

That state of affairs, however, was seemingly threatened by changing libel trends in the 1950s and '60s. Changes in the nation's social and political culture, new dynamics of tort litigation, and new norms and practices of journalism increased the willingness and ability of plaintiffs to sue for libel and to recover damages. In an era

8. Throughout the article I refer to the "libel climate," a phrase introduced by legal scholar Timothy W. Gleason in his study of libel in the nineteenth century. Timothy W. Gleason, The Libel Climate of the Late Nineteenth Century: A Survey of Libel Litigation, 1884-1899, 70 JOURNALISM \& MASS COMM'N Q. 895 (1993). The phrase refers to the broader cultural and social climate that surrounds and influences libel cases. Important features of the libel climate in any given period might include public attitudes towards the press, towards personal reputation, and towards law and litigation, as well the availability of plaintiffs' lawyers. Such factors influence how likely individuals are to sue the press and how judges and juries respond to libel claims against the press. The concept of the libel climate recognizes that the initiation of libel suits and the outcomes of libel cases are dependent on factors outside the boundaries of formal law.

9. Norman Rosenberg, Protecting the Best Men: An Interpretive History of the LaW OF LIBEL 226 (1986). 
when controversies around communism and civil rights, hostility towards the press, and large jury verdicts in tort cases encouraged the use of large-scale libel litigation as a weapon in political and cultural battles, when tort judgments increased nationwide, and when news publications received record-high jury verdicts in libel cases, many news outlets could no longer rely on their established systems for dealing with libel suits, and the likelihood of chilling effects was heightened. This change in the libel climate was not the only force encouraging the Court to institute constitutional protections in libel law, but it was an important factor, one that has been overlooked in standard accounts of the Sullivan case.

This Article describes the libel law history leading up to New York Times $v$. Sullivan. It explores the cultural and legal contexts that surrounded the case, and it suggests the influence of those contexts on the Supreme Court's actions in Sullivan. ${ }^{10}$ Drawing on legal sources, popular literature, journalism, and the archival papers of publishers, it offers an account of how the press accommodated and resisted libel, how libel law shaped the workings of the press, and how the press shaped libel law. The Article focuses on major newspapers (and to a lesser extent, magazines) that dealt regularly with libel issues and libel litigation, and also preserved substantial records of their operations. ${ }^{11}$

This Article chronicles the rise, fall, and partial resurgence of libel as a critical concern for the press in the United States from 1880 to 1964. Part I provides background on the law of libel. Part II describes the development of the masscirculation press in the late 1800s and the many libel suits that accompanied the rise of popular publishing. A surge of libel suits, spurred in part by sensationalistic yellow journalism, posed a formidable burden and near-existential crisis for newspapers in the late nineteenth century. By the early twentieth century, however, the adoption of professional ethics and standards of accuracy and objectivity in journalism, including fact-checking and "libel-vetting" programs at many newspapers, reduced the number of potentially actionable statements and defused the libel crisis. The need to reduce or avoid libel had become an integral part of the professionalization of journalism.

Therefore, by the 1920s, primarily as a result of the press's own efforts, libel had receded to the periphery of the problems faced by most major newspapers. As Part III describes, those elaborate systems of editing and checking for libel, the use of

10. There has been relatively little scholarship on the pre-Sullivan law of libel; this Article begins to fill that gap. One exception is the work of historian Norman Rosenberg, who has conducted extensive research into the pre-Sullivan history of libel. See id.; Norman Rosenberg, The New Law of Political Libel: A Historical Perspective, 28 RUTGERS L. REV. 1141 (1975) [hereinafter Rosenberg, The New Law]; Norman Rosenberg, Taking a Look at "the Distorted Shape of an Ugly Tree": Efforts at Policy-Surgery on the Law of Libel During the Decade of the 1940s, 15 N. KY. L. REV. 11 (1988) [hereinafter Rosenberg, Distorted Shape].

11. Few major publications have preserved the records of their editorial and legal departments. Two notable exceptions are the New York Times and the New Yorker. Extensive documentation of their libel cases and their efforts to deal with libel cases have been preserved in archival collections held at the New York Public Library. Firsthand accounts of journalists' everyday encounters with libel law can also be found in trade journals such as Editor \& Publisher and Nieman Reports, journalism treatises and handbooks, and journalists' memoirs. 
legal counsel to conduct prepublication review, and aggressive litigation strategies kept the number of libel suits and judgments low at most publications. These efforts consumed resources and curtailed some news content. Yet anecdotal accounts from publishers and lawyers suggests that they did not impose stifling burdens on publishing. A fairly broad freedom of the press existed, if not in formal law, then in the law's practical operation.

The 1950s saw the resurgence of libel suits against the press. In the political ferment of the postwar era, an emboldened, well-funded press engaged more forthrightly in political critiques and investigative journalism, and the subjects of such reporting reacted with libel suits. As Part IV describes, the number of libel suits against the press increased, as did the amount of damages claimed and awarded. Many of the press's established strategies for dealing with libel no longer functioned as they once did. Libel law became more of a concern for the press, and libel cases became central to the era's political and culture wars. Against this contentious backdrop, the Supreme Court made its first, historic intervention into libel law in New York Times v. Sullivan.

\section{THE LAW OF LIBEL}

The tort of libel is of old British vintage, dating back to pre-Norman times. ${ }^{12}$ Originally fashioned as a means to deter violence - to stave off "blood feuds" and other forms of physical assault in defense of honor and reputation-libel (written defamation) and slander (oral defamation) were transplanted to America with the rest of the English common law and were subsequently adopted into American political culture. ${ }^{13}$ In the eighteenth century, libel suits typically were brought by public officials over criticism in the press, while slander cases policed the excesses of gossip in small communities - chatter about people's crimes, misdeeds, and sexual affairs. ${ }^{14}$

In order to be actionable as libel, a statement must be both defamatory and false. A defamatory statement is one that seriously lowers a person's reputation in his or her community; it exposes a person to "hatred" or "contempt," "injure[s] him in his profession or trade, or cause[s] him to be shunned or avoided by his neighbours." 15 Reputation typically had a moral dimension. Accusations of having committed a crime, professional incompetence, or having a promiscuous tendency or "loathsome" illness - i.e., a venereal disease - were considered defamatory per se. ${ }^{16}$ In the United States, libel was primarily a civil action. Although statutes prohibiting criminal libel-libel directed against an individual with intent to "breach the peace"- existed in most states until the twentieth century, prosecutions for criminal libel were rare. ${ }^{17}$

12. Roger W. Shuy, The Language of Defamation CASes 10-22 (2010).

13. Id. at $22-28$.

14. ROSENBERG, supra note 9 , ch. 1.

15. William Blake Odgers, A Digest of the LaW of Libel AND SLANDER 18 (1896).

16. Id.

17. RiCHARD LABUNSKI, LiBEL AND THE FIRST AMENDMENT 56 (1987) (noting shift from criminal libel to civil libel in the period after the Civil War); John Kelly, Criminal Libel and Free Speech, 6 U. KAN. L. REV. 295, 317 (1958). 
The plaintiff in a libel case did not have the burden to prove that the statement in question was false or that his or her reputation had actually been harmed. ${ }^{18}$ The plaintiff needed only present the derogatory statement and demonstrate that it could potentially hurt their reputation. The falsity of the statement was presumed; the publisher could exonerate itself by showing that the statement was true. ${ }^{19}$ The defendant was required to prove the truth completely and in all its particulars. Libel was a strict liability tort - the publisher was responsible for its statements regardless of its intent or state of mind at the time of publishing. ${ }^{20}$ Unless the statement fell into one of a few narrow categories of privilege, such as the privilege for reports of legislative or judicial proceedings, malice was presumed. ${ }^{21}$ The only exceptionthe "fair comment" privilege - involved statements of opinion about public officials and public affairs. This exception, which all states had adopted by the late nineteenth century, permitted publishers to make defamatory statements of opinion about public officials in their official capacity or about "matters of public interest and general concern," provided that the underlying facts were true and that the statements were issued with "an honest purpose." 22

Libel law's strictness reflected the high value American society placed on reputation. For merchants, professionals, and tradesmen, a reputation for honesty and good work was the key to success in the commercial marketplace. A woman's reputation for chastity determined her marriageability. Reputation took on particular importance in an increasingly mobile, urban society, where the only way for strangers to learn about each other was through word of mouth. ${ }^{23}$ One writer of the time observed that a good reputation "makes friends; it creates funds; it draws around [one] patronage and support; and opens ... a sure and easy way to wealth, to honor and happiness." ${ }^{24}$ There was particular emphasis in the law on protecting the reputations of political leaders. "[F]alsehood and calumny" against public leaders was "an offense most dangerous to the people, and deserves punishment, because the people may be deceived, and reject the best citizens, to their great injury," wrote the Michigan Supreme Court in 1887. ${ }^{25}$ "Good men" were supposedly deterred from seeking office because of the threat of exposing their private lives to unfair criticism. $^{26}$

18. William Prosser, HANDBOOK OF THE LAW OF TORTS 777 (1941).

19. Id. at 822 .

20. John TOWNSHEND, A TREATISE ON THE Wrongs CALLED SLANDER AND LiBEL: AND ON THE REMEDY BY CIVIL ACTION FOR THOSE WRONGS 104-05 (1890).

21. PROSSER, supra note 18 , at 823.

22. Martin NeWell, The LaW OF Libel AND SLANDER In Civil AND CRiminal Cases 564 (2d ed. 1898).

23. LAWRENCE M. FRIEDMAN, GUARDING LIFE'S DARK SECRETS: LEGAL AND SOCIAL CONTROLS OVER REPUTATION, PROPRIETY, AND PRIVACY 49-53 (2007).

24. Joel Hawes, Lectures AdDressed to THE Young MEN OF HARTFORd AND NEW HAVEN (1828), quoted in KAREN HaltTunen, CONFIDENCE MEN AND PAinted WOMEN: A Study OF MidDLEClass CUlture IN AMERICA, 1830-1870, at 47 (1986).

25. Wheaton v. Beecher, 33 N.W. 503, 506 (Mich. 1887) (quoting Commonwealth v. Clap, 4 Mass. $163,169-70(1808))$.

26. See ROSENBERG, supra note 9 , at 77-78. 
Although there were protections for the press within libel doctrine-the fair comment privilege and the defense of truth - nineteenth century libel law, on the whole, prioritized redress for reputational harm over freedom of publishing. Libel was not seen as raising constitutional issues, either under the U.S. Constitution or state constitutional provisions based on the First Amendment. The legal prohibition of or punishment for publications that had a "bad tendency," that offended people's sensibilities, or that had a "tendency" to create social unrest was seen as a legitimate exercise of the state's police power. ${ }^{27}$ The entry on "freedom of the press" in an 1890 encyclopedia simply described it as "the right to publish, with impunity, the truth, with good motives, and for justifiable ends, whether it respects governments or individuals." 28 This freedom did not protect publications that "from their blasphemy, obscenity, or scandalous character, may be a public offense; or as by their falsehood and malice... may injuriously affect the standing, reputation or pecuniary interests of individuals." 29

\section{THE PRESS AND LIBEL, 1880-1920}

The late nineteenth century saw the emergence of the mass-circulation press in the United States. Innovations in printing technology made large-scale circulation possible, and a literate, expanding urban populace created demand for a constant supply of news. Newspapers became profitable business enterprises. To attract readers and court the advertisers who were their lifeblood, newspapers featured attention-getting, salacious content-stories of murders, kidnappings, affairs, and other scandals. Speed, volume, commercialism, and sensationalism came to define news publishing. So did libel suits. In the last quarter of the nineteenth century, libel became a genuine concern for the press.

\section{A. Libel And the Rise of the Commercial Press}

The American newspaper press flourished in the late 1800s. Between 1870 and 1900, newspaper readership increased by 400 percent, and the number of newspapers doubled. ${ }^{30}$ Urban newspapers attained unprecedented circulation and published up to six or seven editions a day. The aggregate circulation of daily newspapers increased 222 percent between 1870 and 1890, a period when the country's population increased by only 63 percent. ${ }^{31}$ City newspapers sold for a penny or two to appeal to a burgeoning population of immigrants and working-class readers.

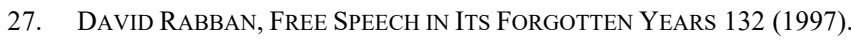

28. 13 The AMERICAN AND ENGLiSh ENCYClOPEDIA OF LAW 510 (John Houston Merrill ed., 1890).

29. Id.

30. Don R. Pember, Privacy and the Press: The Law, the Mass Media, AND the First AMENDMENT 10 (1972).

31. George H. Douglas, The Golden Age OF the NewsPaper 83-84 (1999). 
Major news publishing chains developed, including the Hearst, Scripps, and Pulitzer empires. $^{32}$

Newspapers had once been organs for political parties and were dependent on party coffers for financial support. By the late nineteenth century, most newspapers were commercial enterprises aimed at mass audiences and supported largely by advertising. Publishers assumed the role of businessmen, "involved in the mass production of a commodity that demanded attention to organizational and financial concerns that would have been quite foreign to the crusading political editors earlier in the century." 33 Publishers coordinated production, sales, profits, and news content in what were often expansive, multifaceted operations. Newsrooms grew and diversified; large urban papers were no longer organized around a single editor, but had several editors responsible for different sections, headed by a single publisher. ${ }^{34}$

"Human interest" articles, crime news, and gossip drew in readers and advertisers. In the 1890s, several publishers - most famously, New York's William Randolph Hearst and Joseph Pulitzer-proffered "yellow" journalism, rife with prominent illustrations, large type, and detailed coverage of murders and sexual affairs. ${ }^{35}$ "Muckraking" journalism became a phenomenon in large cities. Reporters were paid to turn out copy quickly, sometimes by the word. There were strong incentives to fabricate stories; objective reporting was not yet a creed. One journalism historian observes that "[r] eporters were sent to get stories and they got them, even if the story was not true." 36

These changes in newspaper production and content created new opportunities to publish inaccurate and defamatory material, and with them, libel suits. Court records, trade journals, and anecdotal evidence from publishers and lawyers indicate that libel suits against newspapers increased sharply between 1880 and $1900{ }^{37}$ From 1884 to 1899, the trade journals The Journalist and The Fourth Estate reported "more than 1,400 libel actions filed by more than 1,200 individual plaintiffs." "38 In 1895, there was a record high of 300 libel cases. ${ }^{39}$ The number of defamation cases appearing before the New York Supreme Court increased by over twenty times between 1870 and $1910 . .^{40}$ One study of a trial court in Wisconsin showed a

\footnotetext{
32. John D. SteVens, Sensationalism AND the NeW York PRESS 65 (1991).

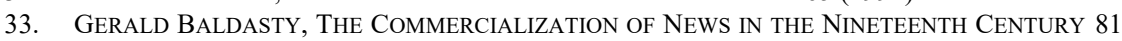
(1992).

34. Id. at $82-85$.

35. David Spencer, Yellow Journalism: The Press And AmericA's Emergence AS A WORLD POWER 87-88 (2007).

36. Ted Curtis Smythe, The Gilded Age Press, 1865-1900, at 65 (2003).

37. ROSENBERG, supra note 9, at 197 ("[E]vidence from appellate courts and literary sources conclusively shows that libel became more common in the late nineteenth century."); TIMOTHY W. Gleason, The Watchdog Concept: The Press And the Courts In Nineteenth-Century AMERICA 66 (1990) ("The number of litigated libel suits exploded after the Civil War.").

38. Gleason, Libel Climate, supra note 8, at 894.

39. Id. at 895 .

40. RANDOlPh Bergstrom, COURTing Danger: INJURY AND LAW IN NeW York City, 18701910, at 20 tbl. 4 (1992).
} 
significant rise in libel suits between 1865 and 1914, most brought against local newspapers. ${ }^{41}$

For many editors and publishers, especially at big-city newspapers, fielding libel complaints became a regular duty. In the 1890 s, libel suits were an "almost daily occurrence" at the Scripps-McRae newspaper chain. ${ }^{42}$ The Chicago Times "had a libel suit almost constantly in progress." 43 At one point it was simultaneously defending twenty-four libel suits, including six by different members of the Chicago City Council. ${ }^{44}$ In 1886, an editor for the New York Times claimed to "always ha[ve] from four to sixteen libel suits on hand." 45

False news was, of course, a libel risk, and even accurate news posed hazards. Typographical and other errors crept into copy easily given the rapid pace of publishing and the volume of printed material. Muckraking articles and sensational crime reports bred libel suits, as did the practice of injecting editorial comments and opinions into news reports. ${ }^{46}$ Reliance on wire services such as The Associated Press also posed dangers. Editors usually didn't check stories that came off the wire, and under existing libel doctrine, every publication that ran a defamatory wire service report could be liable. "Wire service libel," or "chain libel," as it was known, became a feared phenomenon in publishing. In 1904, Wild West entertainer Annie Oakley sued fifty-five Hearst newspapers for a syndicated story claiming that she had stolen a man's trousers to get money to buy cocaine. She accrued over $\$ 42,000$ in damages and settlements, the largest libel recovery in U.S. history to that time. ${ }^{47}$

Libel suits were often politically motivated, brought by political officials and candidates over allegations of scandal and corruption. ${ }^{48}$ During the 1884 presidential campaign, the New York World, known for its political muckraking, faced twentyone libel suits. ${ }^{49}$ Editors and publishers claimed that most libel suits were initiated by public officials 'in malice and to 'get even' with the paper which has exposed them." ${ }^{50}$ In reality, many - if not most - libel claimants were ordinary people who had been written up in human interest stories, gossip columns, and local news. ${ }^{51}$ One of the most common genres of libel cases involved false and sensational accusations of crime. ${ }^{52}$ As newspapers used sexually-tinged gossip about women to

41. Francis Laurent, The Business of a Trial Court 49, 164 (1959).

42. Milton A. MCRAe, ForTy YeARS IN NEWSPAPERDOM 57 (1924).

43. Franc B. Wilkie, Personal Reminisces of Thirty-Five Years of Journalism 231 (1891).

44. Id.

45. Samuel Merrill, NewsPaper Libel: A HandBook for the Press 32 n.1 (1888).

46. GLEASON, supra note 37, at 66-67.

47. Louis Stotesbury, The Famous Annie Oakley Libel Suits, 13 AM. LAw. 391, 392 (1905).

48. GLEASON, supra note 37, at 68-69 (noting that prior to the 1870s, "politicians responded to harsh criticism and falsehood in the press. By the 1870 s, political figures responded to false or questionable charges by filing libel suits.").

49. ROSENBERG, supra note 9 , at 197.

50. PRoceEdings of the Michigan Press Association 31 (1888).

51. Gleason, Libel Climate, supra note 8, at 895-96.

52. GLEASON, supra note 37, at 65 ("Crime news, a staple of the commercial press after the Civil War, was a fertile field for libel litigation from the 1850 s to the end of the century.”). 
sensationalize copy and attract readers, women sued over accusations of unchaste conduct. $^{53}$ Libel plaintiffs came from all walks of life-they were teachers, housewives, clergy, merchants, and lawyers. ${ }^{54}$

Contingent fee practices facilitated many of these libel suits. The 1870 s saw the increased use of the contingency fee agreement, in which a lawyer took a plaintiff's case without any upfront charge. If and when a settlement or judgment was achieved, the lawyer would receive a portion of the damages, anywhere from five to fifty percent. $^{55}$ Such arrangements opened up legal services to the public by allowing plaintiffs to hire attorneys without paying fees up front. ${ }^{56}$ Editors and publishers blamed libel suits on aggressive contingent fee or "damage suit" lawyers. ${ }^{57}$ People were "tempted to try their luck in libel suits and there were too many hungry lawyers eager to aid them," lamented one publishing trade journal. ${ }^{58}$ Newspapers denounced a purported practice among plaintiffs' lawyers of scanning newspapers "every day in search of some story or of some expression that can be construed as libelous."59

This surge in libel suits occurred against a backdrop of public hostility towards the press. The late nineteenth century saw an outpouring of anti-press sentiment, which bred and encouraged libel claims. Newspapers were criticized for their reports of sex, crime, and scandal, and they were blamed for an alleged crisis in public morality. ${ }^{60}$ Public officials and academic commentators called for stronger libel laws. "Nobody wants the libel law changed for the publishers' benefit. Most people would like to have it made more stringent," critic E.L. Godkin observed in $1894 .^{61}$

\section{B. Publishers' Response}

One way that large newspaper publishers responded to these libel suits was by hiring specialized counsel. In 1885, Joseph Pulitzer retained attorney and former Congressman Roscoe Conkling specifically to deal with libel claims against the New York World. ${ }^{62}$ The New York Tribune hired esteemed libel lawyer Henry Woodward Sackett to dispose of the paper's libel suits. ${ }^{63}$ In 1895, the editor of the Denver Republican, facing $\$ 1,200,000$ in libel claims, was forced to hire a lawyer full-time. ${ }^{64}$

53. FRIEDMAN, supra note 23, at 49-53.

54. Peter Karsten, Enabling the Poor to Have Their Day in Court: The Sanctioning of Contingency Fee Contracts, a History to 1940, 47 DEPAUL L. REV. 231, 243 (1998).

55. Peter Karsten, Heart Versus Head: Judge-Made LaW in Nineteenth Century AMERICA 191 (1997)

56. $I d$.

57. Do Not Publish News of Libel Suits, FOURTH ESTATE, July 8, 1897, at 4.

58. Id.

59. A Lawyer on Libel Suits, FOURTH ESTATE, June 13, 1895, at 8.

60. In 1885 President Grover Cleveland decried " $[\mathrm{t}]$ he falsehoods daily spread before the people in our newspapers"; "I don't think there ever was a time when newspaper lying was so general and so mean as at present," he said. MERRILL, supra note 45, at 29.

61. The New Libel Law, NATION, Mar. 22, 1894, at 207.

62. Gleason, Libel Climate, supra note 8, at 905-6.

63. Richard Kluger, The Paper: The Life And Death of The New York Herald Tribune 412 (1986).

64. Gleason, Libel Climate, supra note 8, at 902. 
Relatively few libel cases against the press went to trial. Newspaper lawyers fought wars of attrition, wearing down plaintiffs by filing motion after motion and making strategic delays. ${ }^{65}$ The New York Herald boasted of its strategy in "perfecting" legal delays, and claimed that there was no newspaper of "any standing [that was] not strong enough to fight any libel suit so as to exhaust an ordinary suitor." ${ }^{\text {"6r }}$ Most of the money the Chicago Times paid its lawyer was for "the securing of dilatory action" through a "system of demurring and pleading." 67 Its lawyer explained that "[t]he purpose of delay is to worry and wear out the plaintiff . . by filing demurrers and taking action which we know will not be sustained, but which will delay the final trial, and in that way we sometimes drive a man from the field." 68

When libel cases were tried, the press often succeeded. In 1883, the Baltimore American reported that it had dealt with fifty libel suits seeking \$2 million dollars in damages and paid only $\$ 500$ to plaintiffs. ${ }^{69}$ The Associated Press claimed that libel judgments cost it "less than the expenditure for lead pencils." " Juries often favored the press, especially when plaintiffs were public officials, a tendency attributed to public mistrust of politicians. ${ }^{71}$ Press advocates credited juries with "saving" newspapers from "utter ruin." 72 But publishers did not escape liability altogether. Plaintiffs, especially private citizens, did recover substantial judgments, ranging from a few hundred to several thousand dollars. ${ }^{73}$

Even if they didn't result in unfavorable verdicts, libel lawsuits imposed significant burdens on the press, as publishers recognized keenly. Legal fees could be formidable. ${ }^{74}$ In 1895 , the Denver Republican was the defendant in a libel case that ended in a verdict for $\$ 650$ but cost about $\$ 25,000$ in lawyers' fees. ${ }^{75}$ According to the Philadelphia Times in 1888, the paper had paid over $\$ 20,000$ for legal defense over the previous thirteen years, even though it received a favorable judgment in every case. ${ }^{76}$ Libel suits also had nonpecuniary costs; they could diminish the morale of newspaper staff and tarnish a publication's reputation. ${ }^{77}$ A libel judgment against a paper, or negative publicity in connection with a libel case, "would be taken up by a rival publication, to the injury of the offending party and the profit of the rival," observed one editor. ${ }^{78}$

65. WILKIE, supra note 43, at 231-32.

66. Alfred MCClung Lee, The Daily NewSPAPER IN AMERICA 416 (1937).

67. WILKIE, supra note 43, at 232.

68. Id.

69. Newspaper Libel Suits, St. Louis Post-DisPatch, May 2, 1883, at 4.

70. Adolph S. Ochs, Associated Press Serv. Bull., Apr. 25, 1918, at 7.

71. See MERrill, supra note 45, at 207 ("Writers for the press are ... generally allowed greater latitude by juries.").

72. Concerning Libel Laws in Iowa, ED. \& PuBLISHER, Mar. 4, 1916, at 1196.

73. Gleason, Libel Climate, supra note 8, at 899-901.

74. The Crying Need of Libel Law Reform, FourTh ESTATE, Apr. 2, 1904, at 10.

75. Gleason, Libel Climate, supra note 8, at 902.

76. Id. at 905 .

77. A Bill to Protect Newspapers from Blackmail, BRoOKLYN DAILY EAGLE, Apr. 6, 1883, at 2.

78. Id. 
Publishers worked with state and national newspaper trade associations in efforts to secure statutory revisions to libel laws. ${ }^{79}$ In the $1880 \mathrm{~s}$, libel litigation was identified as a major industry problem by the newly formed American Newspaper Publishers Association (ANPA). The ANPA engaged in numerous campaigns to liberalize libel law under the rallying cry of "freedom of the press." 80 Press associations saw statutory reform as critical, since courts had largely resisted the efforts of the press to widen the scope of existing privileges. In the late nineteenth century, there was almost no movement in the common law of libel. ${ }^{81}$ Libel law remained nearly as restrictive as it had been half a century earlier.

\section{C. “Libel Vetting” and the Professionalization of Journalism}

Facing the increasingly onerous burden of defending libel suits and few prospects for legal change, publishers began focusing their energies on preventive measuresediting and checking copy to prevent potentially libelous material from being published. By the early twentieth century, these practices, known in the field as "libel vetting," had become standard at many newspapers. In conjunction with a new emphasis on impartiality and accuracy in reporting, libel vetting yielded substantial reductions in libel claims. ${ }^{82}$

Libel vetting had benefits beyond avoiding libel. Checking copy to avoid inaccurate and potentially defamatory statements supported the ideals of truthfulness and fairness that accompanied the professionalization of journalism. Avoiding libel meshed with a nascent vision of journalism as a profession guided by principles and standards and as a "public service" devoted to civic betterment through the dissemination of truthful facts. Responsible newspapers were not taken to court regularly to defend themselves in libel cases. The quest to avoid libel became both a measure to protect a newspaper's finances and part of journalism's efforts to develop a new image of legitimacy and credibility.

\section{The Professionalization of Journalism}

The movement to professionalize journalism was inspired by similar professionalization movements in medicine, law, engineering, and education. In the late nineteenth century, institutions for professional training, as well as credentialing systems and ethics codes, had been created in those fields. ${ }^{83}$ Journalism's $^{2}$

8 .

79. GLEASON, supra note 37, at 66; Demand Better Libel Laws, FOURTH ESTATE, Mar. 7, 1895, at

80. See GlEASON, supra note 37, at 69; see also EDWIN EMERY, History OF THE AMERICAN NEWSPAPER PUBLISHERS ASSOCIATION 49-50 (1970).

81. In the $1860 \mathrm{~s}$ and ' $70 \mathrm{~s}$, a handful of states had adopted a conditional privilege for statements about public officials and public affairs made with good faith belief in their truthfulness, but enthusiasm for the privilege waned in the last quarter of the century. See ROSENBERG, supra note 9, at 178.

82. See Hall, supra note 3, at 37 ("Newspapers reacted by setting their own professional standards and those professional standards ended up curbing the incidence of these suits, because to be professional was not to be sued. The way to show that you were a professional newspaper person was not to end up in court trying to defend yourself in a libel action.").

83. BetTy Houchin Winfield, Journalism, 1908: Birth of A PROFESSION 3 (2008). 
professionalization also grew out of critiques of yellow journalism, which peaked during the Spanish American War of 1898. The yellow press had been accused of sparking American involvement in the war through exaggerated, falsified news. ${ }^{84}$ As the public pressed for laws to regulate newspaper content, including the outlawing of false news, publishers were motivated to self-regulate in order to stave off formal legal control. ${ }^{85}$

The Progressive movement, with its emphasis on expertise and the dissemination of facts as a means of ameliorating social ills, was also a force behind journalism's professionalization. ${ }^{86}$ Reporters were encouraged to view themselves as investigators and "scientists" uncovering "economic and political facts" and reporting them in an objective manner. ${ }^{87}$ Many publishers adopted the mantle of civic responsibility. News was to serve a public function, providing readers the credible facts they needed to make decisions as informed citizens in a democratic society. ${ }^{88}$ By 1910 , several state publishing associations had promulgated ethics codes stressing fairness, truthfulness, and public service. ${ }^{89}$ The American Society of Newspaper Editors issued its influential code in 1922, exhorting journalists to make "[e]very effort ... to assure that news content is accurate, free from bias and in context, and that all sides are presented fairly." 90

Graduate schools of journalism and professional associations were founded, and a body of professional literature developed around reporting and editing. ${ }^{91}$ Handbooks for writers and editors, many dealing with libel law, were produced in large volume. Though tabloids and "scandal sheets" continued to be published, sensationalism and outright fakery had been curtailed and clear lines drawn between opinion and news. Many news outlets actively cultivated a public image and professional identity oriented around civic-mindedness, neutrality, and truthtelling. ${ }^{92}$

Publishing inaccurate and defamatory material ran counter to these new aspirations. Having a reputation for publishing libel and being sued for libel was

84. David Paul Nord, Accuracy or Fair Play? Complaining About the Newspaper in Early Twentieth Century New York, in New Directions in American ReCEPTION STUdy 233, 235 (Philip Goldstein \& James Machor eds., 2008) ("Rapid growth in the size and power of newspaper corporations, rising influence of big advertisers and commercial interests, ugly circulation wars in major cities, and reckless sensationalism, especially in the New York press, had combined to bring the industry under fire from all sides.").

85. See id.

86. Michael Schudson, Discovering the News: A Social History of American NEWSPAPERS 71 (1978).

87. Id.

88. Nord, supra note 84 , at 235.

89. See Stephen Banning, The Professionalization of Journalism: A Nineteenth Century Beginning, 24 JOURNALISM HIST. 157-64 (1998).

90. ASNE Statement of Principles, NEWS LEADER ASs'N, https://perma.cc/NUC6-P5CA (last visited Jan. 27, 2021).

91. Nord, supra note 84, at 235. The Missouri School of Journalism was founded in 1908, and the Columbia School of Journalism in 1912. See WinfIELD, supra note 83, at 8.

92. See SCHUDSON, supra note 86, ch. 5 . 
associated with partisanship, irresponsibility, and faking news. Fidelity to facts became the core of professionalism, and it was also the essence of avoiding libel.

\section{2. "Libel Avoidance"}

In the early twentieth century, several newspapers implemented libel vetting programs that ranged from the rudimentary to the formal. Some publications relied on a single editor, armed with a libel handbook, to screen copy. Others devised more comprehensive systems that implicated a variety of newspaper staff, including reporters, news editors, copy editors, and headline writers.

Under new "libel avoidance" protocols, reporters were warned of the dangers of libel and told that the "worst thing that could happen" to them was involving their paper in a libel suit. ${ }^{93}$ When H.L. Mencken started at the New York Herald in the 1890 s, the paper's management told him to verify reports whenever possible, "be careful about names, ages, addresses, and figures . . . [and] keep in mind at all times the dangers of libel."94 City editors, in charge of local news and crime news, were responsible for reading articles "particularly carefully for cases of possible libel," always proceeding under the rule that "nothing libelous must be passed" along. ${ }^{95}$ Copy editors and managing editors were instructed to mark suspicious articles for destruction. Manuals on libel law were issued for newspaper workers, such as Henry Sackett's The Law of Libel: What Newspaper Men Should Know About It, considered a classic in the field. ${ }^{96}$ Journalism schools began offering courses on libel. The first curriculum in journalism at the University of Missouri featured a course entitled "Newspaper Jurisprudence," described as a "study of the laws that relate to newspaper publication, particularly the laws relating to libel."97

The New York World was an innovator in the emerging field of libel avoidance. In 1913, it established a Bureau of Accuracy and Fair Play to prevent libel suits by promoting "accuracy among staff." 98 In its mission statement, the Bureau declared that "accuracy and fair play" were not only integral components of responsible journalism but also the antithesis of libel: "Accuracy and fair play . . . is a test which, if applied by writers and editors to articles designed for publication, would almost invariably lead them safely through the intricate mazes of libel law." 99 The Bureau aimed to reduce the expenditure of libel suits and the "loss of prestige to the ... newspaper which the trial of such suits certainty engenders." 100 All

93. JOHN L. GIVEN, MAKING A NEWSPAPER 172 (1907).

94. H.L. MENCKEN, NEWSPAPER DAYS, 1899-1906, at 14 (1940).

95. Chauncey Rathbun, Editing a Metropolitan Newspaper, BULL. OF THE UNIV. OF WASH., THE BETTER NEWSPAPER 57, 60 (1914).

96. Henry Sackett, The Law of Libel: What Newspaper Men Should Know About It (1885), reprinted in HENRY WOODWARD SACKETT, THE LAW OF LiBEL: WHAT EVERY NEWSPAPER MAN IS EXPECTED TO KNOW ABOUT IT 7 (1929).

97. General Catalog, Univ. OF Missouri 268 (1912).

98. Nord, supra note 84 , at 236 ("[L]ibel was clearly the most pressing concern of the founders of the Bureau of Accuracy and Fair Play.")

99. A. C. Haeselbarth, World's Bureau of Accuracy, ED. \& PUBLISHER, Nov. 15, 1913, at 436.

100. Concerning Libel, ED. \& PUBLISHER, Jan, 11, 1913, at 24. 
complaints received by any department in the World were turned over to the Bureau. If the complaint was deemed to be well-founded, a correction was prepared and published. ${ }^{101}$ During its first year of existence, the Bureau considered 432 complaints and published 164 corrections. ${ }^{102}$ According to the World, the Bureau enhanced the paper's reputation, created good will among readers, and decreased libel suits. ${ }^{103}$ Other newspapers adopted similar programs. ${ }^{104}$

Avoiding libel and fulfilling the newspaper's civic and professional duties were paired as complementary goals. If a publication adhered to journalistic ethics, "the danger of libel or other embarrassment [would be] reduced to a minimum," wrote Editor \& Publisher in 1917. ${ }^{105}$ "A successful paper is seldom sued for libel with the result that the paper is held for damages." 106 Publishers who had lived through the "old days" pointed to the decline of libel suits as a sign of progress in the field. "The day of "blackleg' journalism has passed, and ethical standards ... have taken the place," observed one newspaper trade journal. ${ }^{107}$

\section{EQUILIBRIUM, 1920-1945}

By the 1920s, libel had receded to the margins of the problems faced by the press in its daily operations. ${ }^{108}$ "Libel actions ... are rare things," a publishing journal announced in 1922. ${ }^{109}$ Libel actions declined rapidly after World War I as the passing of "the 'yellow' journalist set the stage for the factual news report, the modulated editorial page, the premium on greater effort at accuracy rather than glib vituperation," writes one journalism scholar. ${ }^{110}$ As historian Norman Rosenberg noted, libel was barely a problem for American newspapers during the 1930s and 1940s. ${ }^{111}$ The "libel climate" had transformed.

Existing statistics bear this out. Between 1923 and 1948, the New York Times was the defendant in only eighty-five libel suits. ${ }^{12}$ From 1939 until 1959, the paper

101. The Coming Newspaper 322-23 (Merle Thorpe ed., 1915). The Bureau compiled a card index of staff members responsible for inaccuracies. Amassing too many notations was a sign of "carelessness or unfairness [that] may be punished by reprimand, suspension, or dismissal." Id. at 323.

102. Id.

103. Neil Nemeth, News Ombudsmen in North America 23 (2003).

104. Id. Among them were the Minneapolis Tribune, Sacramento Bee, and Philadelphia Ledger.

105. Some Rules for News Writers, ED. \& PUBLISHER, Oct. 13, 1917, at 17.

106. Rathbun, supra note 95 , at 60.

107. Joseph Ruffner, Jr., Libel, 7 WASH. NEWSPAPER 97, 99 (1922).

108. ROSENBERG, supra note 9 , at 226

109. Ruffner, supra note 107 , at 99.

110. William SWindler, Problems of LAW IN JOURNALiSM 103 (1955); see also id. at 102 ("In the past fifty years much of this change has been the result of revised journalistic practices; in the nineteenth century the excess of political party journalism, as well as the news-writing style which called for use of vigorous epithet and gratuitous comment intermingled with fact brought many a newspaper to grief and litigation.").

111. ROSENBERG, supra note 9, at 226.

112. Letter from George Norris to Godfrey Nelson, Oct. 28, 1948, in ARTHUR HAYS SUlZBERGER PAPERS (on file with New York Public Library, Manuscripts and Archives Division, Box 196, Folder 17). 
averaged a little more than one libel suit a year. ${ }^{113}$ Between 1932 and 1942, the New Yorker was taken to court for libel only a handful of times. ${ }^{114}$ The New York World was sued for libel on average only eleven times each year between 1910 and $1930 .{ }^{115}$ Small and mid-sized newspapers around the country also reported few libel claims. ${ }^{116}$

The New York Times paid judgments or settlements in only ten of the libel suits it defended. ${ }^{117}$ Of the $\$ 16,344,284$ in libel damages the Times was sued for over thirty years, it paid only $\$ 43,987$ to plaintiffs. ${ }^{118}$ According to the paper's lawyer, "[i]t would seem that if anyone had an idea of getting rich quick, he would be better off looking for uranium than suing the New York Times for libel." 119 In the 220 libel suits faced by the New York World between 1910 and 1930, the paper paid judgments or settlements worth approximately $\$ 5,500$ a year. ${ }^{120}$ Over twenty-nine years, the New York Herald Tribune lost only one libel case. ${ }^{121}$ These figures are notable given the large volume of printed material in circulation. Daily newspaper circulation increased from 22.4 million copies in 1910 to 39.6 million copies in the 1930s. ${ }^{122}$ The New York Times was circulating 440,086 copies daily by the 1940s, and the Chicago Daily Tribune, 1,005,992 copies. $^{123}$ By 1925, almost 4,500 different periodicals were published annually. ${ }^{124}$

As this Section describes, the press's defeat of its libel problem was not the result of any substantial change in the law, but rather the work of the press through its efforts to employ trained libel counsel, "hit back" hard in libel cases, ${ }^{125}$ and "stop[] defamatory copy from getting into print." 126 By 1930, it was accepted wisdom in the field that prevention was the best defense against libel, and that " $[t]$ he best protection is ... to have an editorial staff so well ... trained that defamatory stories or articles

113. Id.

114. Kathy Roberts Forde, Literary JournaLism On Trial: MASSON V. NEW YORKER AND THE FIRST AMENDMENT 96-97 (2008).

115. Frank Thayer, The Changing Libel Scene, 1943 WIS. L. REV. 331, 333 (1943).

116. See, e.g., IRA NiCHOLS, FORTY YEARS OF RURAL JOURNALISM IN IOWA 218 (1938). ("During our life's work in the newspaper field, we have been sued for a total of $\$ 335,000$ for libel. . . . No verdict for damages was ever rendered against us.... [W] e were able to defend ourselves at a total cost of around $\$ 3,000 . ")$.

117. Letter from Adolph Ochs to Alfred A. Cook, May 9, 1922, in ADOLPH OchS PAPERS (on file with New York Public Library, Manuscripts and Archives Division, Box 86, Folder 6) [hereinafter Ochs Policy].

118. Id.

119. Norris, supra note 112 , at 10.

120. Thayer, supra note 115 , at 333-34.

121. KLUGER supra note 63, at 411.

122. Lyn Gorman \& DAVid MCLean, Media and Society into the 21st Century: A HISTORICAL INTRODUCTION 24 (2009).

123. Thayer, supra note 115 , at 331 .

124. DaVid E. KYVIG, Daily Life IN THE United StATES, 1920-1939, at 162 (2002).

125. C. Dickerman Williams, What's Wrong in Libel, NAT. REV., Mar. 25, 1961, at 185.

126. Thayer, supra note 115, at 334 . 
will not get by the copy desk." 127 It was also seen as prudent to have "competent counsel." 128

\section{A. The Libel Prevention and Defense System}

In the 1930s and '40s, publications honed their libel vetting systems. ${ }^{129}$ Elaborate editing and fact-checking programs at major newspapers involved all editorial personnel, as well as specialized lawyers. Publishers aspired to cultivate "libelconsciousness" among their staff ${ }^{130}$ and were known to fire those whose ignorance or negligence embroiled the publication in "libel trouble."

\section{Editorial and Legal Vetting}

Editors and reporters continued to be trained in the perils of libel. Publishers offered libel education and "libel talks" to their staff, and libel treatises were placed in newsrooms. ${ }^{132}$ Reporters were taught to be "libel savvy." It was no longer enough to "get the facts"; reporters also had to be conscious of liability. Journalists were told to make no assertions about a person's conduct or character without first "mak[ing] certain that there is something on permanent record somewhere which [they] could present if necessary as absolute proof of [their] statements." 133 Unsupported conclusions or careless newsgathering increased the likelihood of "expos[ing one's] newspaper to the danger of a libel suit." 134 Editors fact-checked material, altered language, and in some cases, threw out entire stories. ${ }^{135}$ The St. Louis Republic gave each of its copy editors a "vest pocket card containing libel warnings," titled "Look At This Every Day." 136

Editors and reporters were assisted by so-called "vetting lawyers." By the 1930s, several major publications employed lawyers for prepublication review-checking finished articles for potentially libelous statements prior to publication. In 1937, a publishing trade journal noted that half of the major New York newspapers used lawyers as "censors."137 Three of New York's nine major newspapers were fully vetted before printing. ${ }^{138}$ Each day a lawyer read the first edition of the paper and

127. Frank Thayer, Legal CONTROL OF THE PRESS 221 (1962).

128. Id.

129. M. Marvin Berger, Detecting Libel Before It Appears, ED. \& PUBLISHER, May 29, 1937, at 7.

130. Harold Cross, Current Libel Trends, NiEMAN REP., Jan. 5, 1951, at 7.

131. Buford Otis Brown, Problems of NewsPAPER Publishing 299 (1929).

132. Cross, supra note 130, at 7.

133. William E. HALL, REPORTING NEWS 404 (1936).

134. Id.

135. On the fact-checking department at Time, Inc., see SAMANTHA BARBAS, NEWSWORTHY: THE Supreme Court BAtTle Over Privacy AND Press FreEdom 83-85 (2017) [hereinafter BARBAS, Newsworthy]; at the New Yorker, see Ben Yagoda, ABout Town: The NeW Yorker AND THE World It MADE 202 (2001); at the New York Times, see Ochs Policy, supra note 117.

136. CHARLES GRIFFITH Ross, THE WRITING OF NEWS 178 (1911).

137. See Berger, supra note 129 , at 7.

138. Id. 
made corrections or deletions and suggested changes. ${ }^{139}$ Sometimes this resulted in deleting an entire story. More often, it led to checking facts or changing languagerephrasing statements as opinion or bringing them within recognized privileges to make them libel-proof. ${ }^{140}$ Syndicated columnist Drew Pearson, who faced over 100 libel claims during his career and won all but one, was famous for working with lawyers to make his columns "libel-proof."141

Prepublication review was credited with reducing libel claims and legal expenses at most newspapers. ${ }^{142}$ As a result of rigorous prepublication checks, two newspapers in Boston and two in Washington almost entirely eliminated libel suits. ${ }^{143}$ "Legal censorship," if "intelligently used," can result in "considerable saving to any newspaper of large circulation," the trade journal Editor \& Publisher promised in $1937 .{ }^{144}$

\section{Defending the Press}

When libel cases were litigated, large news publications were known to deploy aggressive defenses. ${ }^{145}$ Newspapers made strategic use of libel lawyers and relied on the press's typical advantages over plaintiffs. Large and relatively prosperous urban newspapers could pursue libel cases over long periods of time, whereas plaintiffs often wearied or ran out of funds and abandoned their claims. Publishers benefited from their lawyers' specialized expertise in libel, compared to plaintiffs' counsel, who were generally less experienced with libel cases. ${ }^{146}$ By the 1930s, a handful of firms specializing in libel law had been established in New York, and several large firms had libel experts that assisted large newspapers and media enterprises. $^{147}$

139. Id.

140. Id. Lawyer "[r]eadings often disclose a statement which needs proof before it can be retained, or some phrasing which needs correction because it is obviously dangerous." J. K. Lasser, Publishers, Corner, SATURDAY REV. OF LiterATURE, July 15, 1950, at 26.

141. Douglas Anderson, Drew Pearson: A Name Synonymous with Libel Actions, 56 Journalism Q. 235, 242 (1979); see also DOUglas ANDERson, A WASHINGTON MERry Go ROUND of Libel ACTIONS 253 (1980) ("The care Pearson took in formulating potentially libelous phrases cannot... be overemphasized.").

142. Richard Donnelly, The Right of Reply: An Alternative To an Action for Libel, 34 VA. L. REV. 836, 879 (1948); Alvin VAN BENTHUYSEN, NEWSPAPER ORganizATION AND ACCOUNTING 20 (1932). In 1924, the New York World paid $\$ 108,000$ to settle all its pending libel suits, then issued a system of prepublication review. During the next seven years it never paid out more than $\$ 5,500$ in libel judgments or settlements a year, and most years its expenses totaled less than $\$ 1,500$. See Rosenberg, supra note 9 , at 225 .

143. Berger, supra note 129 , at 7 .

144. Id.

145. Williams, supra note 125 , at 185 .

146. Law professor David Riesman noted in his 1942 study of libel that "diverse and unknown counsel appear for the plaintiff in most suits," even in New York, where most of the cases originated. David Riesman, Democracy and Defamation: Fair Game and Fair Comment II, 42 Colum. L. Rev. 1282, 1285 (1942) [hereinafter Riesman, Fair Comment II].

147. Their principals were renowned specialists in the field, including Morris Ernst and his colleague Alexander Lindey, who represented the New Yorker; Henry Sackett, who represented the New York Herald Tribune; and Macdonald De Witt, who worked for several newspapers and was regarded as one of the 
Major press outlets were often reluctant to settle libel claims. ${ }^{148}$ The New York Times and the New Yorker had strict rules against settling libel cases, in order to discourage so-called nuisance suits. ${ }^{149}$ As publishers hoped, plaintiffs often abandoned their claims readily. ${ }^{150}$ Recalled one newspaper lawyer, in nine times out of ten, starting a lawsuit was "the safety valve blowing off, and the case never reaches the trial calendar." 151 Plaintiffs often desisted when they realized what might come out in discovery. ${ }^{152}$ Since both liability and damages depended on the plaintiff's reputation before the allegedly defamatory statement, the publication had an incentive to introduce evidence that would, in the words of one lawyer, "decimat[e] the reputation and character of the plaintiff." 153 Large publications had employees who " $\mathrm{d}[\mathrm{u}] \mathrm{g}$ up all the misfortune in the plaintiff"s past." 154 Some publications hired former FBI agents as investigators. ${ }^{155}$ Plaintiffs often backed down when they found out they were under investigation. As one libel lawyer observed, "it is said that when a person begins a suit for libel he is inviting an investigation into his past life beginning with his birth. Much has been spent for such investigations. We think they pay off, for sometimes the knowledge of someone's asking questions about him is enough for him to call it quits." 156

foremost authorities on libel law. On Greenbaum, Wolff and Ernst, see FORDE, supra note 114, at 93-95; Samantha Barbas, The Sidis Case and the Origins of Modern Privacy Law, 36 COLuM. J.L. \& ARTS 36 (2012). On DeWitt, see Burton Rascoe, Libel Lawyer: Macdonald De Witt, EsQuiRE, Aug. 1938, at 52. Cravath, Swaine \& Moore represented Time, Inc., and Lord Day \& Lord began handling the New York Times' libel cases in the 1940s. See BARBAS, NEWSWORTHY, supra note 135, at 86-87.

148. See Rascoe, supra note 147, at 52.

149. Wrote Times publisher Adolph Ochs to the paper's lawyers: "You know my views about settling libel suits.... I would never settle a libel suit to save a little money.... If we have damaged a person we are prepared to pay ... and we accept the decision as part of the exigencies of our business." Ochs was credited with popularizing the "no-settlement" policy at major newspapers. Ochs Policy, supra note 117. On the New York Herald-Tribune's "no-settlement" policy, see KLUGER, supra note 63, at 411.

150. As David Riesman observed in 1942, the public had become familiar with the "phenomenon of a maligned politician publicly announcing that he is consulting his lawyers, and that he is filing a libel suit asking for six or seven figures in damages - a suit allowed to drop when the incident blows over." David Riesman, Democracy and Defamation: Fair Game and Fair Comment I, 42 CoLuM. L. Rev. 1085, 1086 (1942) [hereinafter Riesman, Fair Comment I].

151. Norris, supra note 112 ("There are more libel actions started than ever brought to trial. Many are filed merely as a scare and are subsequently withdrawn.").

152. Lasser, supra note 140 , at 26.

153. Id.

154. Barbas, Newsworthy, supra note 135 , at 88 . See also Morton SOnTHEIMER, Newspaperman: A BooK About the Business 113 (1941) ("Their jobs, officially, are to get confirmation of charges on which libel actions have been brought.... However, their duties not infrequently go beyond getting confirmation of the specific charges to the point of getting anything at all on the plaintiff, a little blackmail being resorted to....").

155. Kluger, supra note 63, at 413. See also Laurence Eldredge, Practical Problems in Preparation and Trial of Libel Cases, 15 VAND. L. REV 1085, 1085 (1961) ("One who has skeletons in his own closet is foolish to press a libel action, particularly against a large newspaper. The institution of suit against the newspaper usually results in the most thorough investigation of the plaintiff's entire life.").

156. Norris, supra note 112. 
As in the past, relatively few libel cases went to trial. ${ }^{157}$ Publications depended on their lawyers' well-established strategy of wearing down the plaintiff through motions and intentional delays. John Donovan, the lawyer for Drew Pearson, would inundate the courts with procedural filings. It was not unusual for an action filed against Pearson to drag on for five years; it became practically a full-time job for the plaintiffs' attorneys to answer Donovan's motions. ${ }^{158}$ The press continued to prevail in the majority of libel trials. Trial attorney Arthur Train commented in 1939 that "[a] successful libel suit is, at best, almost as unusual as a successful action to break a will. It is the rare-very rare-exception." 159 According to one source, newspapers won libel suits seven out of eight times, and half of their losses were overturned on appeal. ${ }^{160}$

\section{B. A Chilling Effect?}

Every day, editors and lawyers cut, reworded, and modified articles to avoid the possibility of libel suits. ${ }^{161}$ How did this caution affect the news? Did the fear of libel inhibit newspapers from criticizing the government or reporting news on matters of public concern?

Lawyers, scholars, editors, and publishers of the period expressed divided views on libel law's impact on reporting. Some denounced the law as a "restriction upon the legitimate and desirable freedom of the press" "162 but others described it in less ominous terms. One editor told First Amendment scholar Zechariah Chafee that libel law "works well although it looks bad on paper. No newspaper editor has just cause for complaint."163

Some editors described "timidity" in the coverage of local news induced by fear of libel suits. ${ }^{164}$ One vetting attorney claimed that it was difficult to "censor" without injuring the message and "piquancy of the story."165 A managing editor blamed lawyers for "taking the easy way out" and ordering stories to be deleted, rather than "work[ing] harder ... to figure out how we could publish a piece."166 Smaller

157. Less than half of one percent of libel cases that were initiated were actually tried. Donnelly, Right of Reply, supra note 142, at 869 n.5. In general, defamation cases made up a very small percentage of litigated cases. See Charles Edward Clark \& Harry Shulman, A Study of LaW ADMINISTRATION IN CONNECTICUT 13 (1937) (noting that less than one percent of cases before the court were libel and slander suits).

158. Anderson, supra note 141, at 241-42.

159. ARTHUR Train, MY DAY IN COURT 234 (1939).

160. Ruffner, supra note 107, at 99.

161. See, e.g., NANCY BARR MAVITY, THE MODERN NeWSPAPER 160-61 (1930) (urging reporters to "lean[] over backward" to avoid writing anything that "might possibly be construed as libelous," and to avoid "any words to which offense might be taken.").

162. William Prosser, Interstate Publication, 51 MICH. L. REV. 959, 993 (1953).

163. ZECHARIAH CHAFEE, GOVERNMENT AND MASS COMMUNICATIONS, VOL. 1, at 103 (1947).

164. Id. at 101.

165. Berger, supra note 129 , at 7.

166. FORDE, supra note 114, at 95. 
newspapers were known to be more cautious about potential libels compared to their larger and better-funded counterparts. ${ }^{167}$

Yet others were more optimistic about the balance between libel and press freedom. According to the journalism publication Nieman Reports, the press had broad latitude to publish despite libel; fear of libel was a "relatively minor influence" on the average reporter's work. ${ }^{168}$ The New Yorker's lawyers boasted that they had managed to keep the publication out of libel trouble "without cramping the style or dulling the barbs of . . . editors and contributors." 169 "Only rarely [was] it necessary to suppress a story in its entirety," said one lawyer who vetted copy for a newspaper. ${ }^{170}$ Even when a story was deleted, it was primarily due to concerns about accuracy, not fear of libel. ${ }^{171}$ According to one lawyer, "the law did not make much of a difference in what a newspaper would say. By a change of phrasing and leaving out a specific name, the paper can say the same thing and protect itself from libel charges." $" 172$

Most in the field agreed that the potential chilling effect of libel law was mitigated by the relative ease of avoiding libel suits. This created a kind of de facto freedom: built-in breathing room for the press. ${ }^{173}$ It was well known that editors and publishers frequently took libel risks when they thought material had great civic (or in some cases, commercial) value; newspapers "print[ed] potentially libelous material because many people libeled [were] not in a position to sue the paper." 174

"A paper which doesn't take chances is a dead paper," noted Stanley Walker of the New York Herald Tribune. 175 "A too close attention to the absolute rules regarding libel ... might result in a product which is flat, insipid, devoid of all those adornments of narrative, epithet, and description which make a great newspaper a living thing." 176 "Most present-day newspapers knowingly print potentially libelous statements," asserted one lawyer. "They do so because otherwise they would have a very dull paper." 177 New York Times managing editor Carr Van Anda checked and rechecked his stories to avoid libelous statements. At the same time, "he would take the boldest of chances if he felt that he owed it to his readers." 178

167. There is no evidence of any publication being bankrupted from libel judgments or legal defense of libel cases. But see Donnelly, Right of Reply, supra note 142, at 878 ("The smaller journals, struggling along on subsidies or barely managing on their own, are highly vulnerable to libel suits whereas the large enterprises have no crusading spirit or else can stand the expense of litigation.”).

168. History in a Hurry, NiEMAN REP., Apr. 1950, at 15.

169. FORDE, supra note 114, at 97.

170. Berger, supra note 129 , at 7.

171. CHAFEE, supra note 163, at 101 ("Talk about a libel suit is often used by newspapers as an excuse for cautious conduct which is really otherwise motivated.").

172. Id. at 102 .

173. Morris L. ERNST \& AlEXANDER Lindey, Hold Your TONGUE: AdVENTURES IN Libel AND SLANDER 193 (1932).

174. THOMAS ELLIOTT BERRY, JOURNALISM IN AMERICA 21 (1976).

175. STANLEY WALKER, City EDITOR 186 (1934).

176. Id.

177. BERRY, supra note 174 , at 21.

178. BARNETT Fine, A GiANT OF THE PRESS 51 (1933). 
Editors and publishers sometimes overrode their lawyers' advice when it conflicted with their own agendas. An eminent attorney who worked on libel vetting recalled that his suggestions often clashed with the editors' views and were overridden. ${ }^{179}$ The New Yorker's editors were known to overrule their lawyers and publish stories without "getting into any [legal] trouble at all."180 At times, "[t]he courageous editor ha[d] to consult his own conscience, instincts, and experience." 181

As Buford Otis Brown observed, "[t]here are times when any self-respecting publisher must go ahead." 182 Under some circumstances, "the public good depends upon risking the danger of [a] libel action and its cost," which could be absorbed by the publication or passed off to readers and advertisers. ${ }^{183}$

By the 1940s, many members of the press felt they had achieved a workable compromise with the law of libel. One editor of a mid-size New York newspaper stated that the press had "no great difficulty" under libel law, as "[t]here are few libel suits today." 184 An insurance company began offering libel insurance in the 1930s, but few publishers purchased it because they felt that the risk of libel suits was negligible and did not justify the cost of insurance. ${ }^{185}$

\section{The "Libel Climate" of the 1930S AND "40S}

Libel law and libel lawsuits remained a topic of public interest, and high-profile cases continued to make the news. News media regularly featured stories about lawsuits threatened and filed, often involving celebrities or politicians. ${ }^{186}$ As David Riesman observed, the public had become familiar with the "phenomenon of a maligned politician publicly announcing that he is consulting his lawyers and filing a libel suit seeking six or seven figures in damages - a suit allowed to drop when the incident blows over." 187

Publishers, their lawyers, and trade associations continued to lobby for changes in the formal laws of libel, with relatively little success. The American Newspaper Publishers Association, the American Society for Newspaper Editors, and state newspaper associations embarked on campaigns to effect revisions of the laws on privilege and laws on retractions and damages. There were some press-friendly developments. Some courts began moving away from requiring "proof in exact, precise, and complete detail" in the truth defense. ${ }^{188}$ By 1950, one quarter of states

179. Berger, supra note 129 , at 7 .

180. FORDE, supra note 114 , at 95 .

181. CHARLES ANGOFF, THE BOOK OF LIBEL 28 (1966).

182. BROWN, supra note 131 , at 297.

183. GRANT MILNOR HYDE, HANDBOOK FOR NEWSPAPER WORKERS 196 (1921); On loss-spreading, see Richard Donnelly, The Law of Defamation: Proposals for Reform, 33 MinN. L. REV. 609,614 (1948) ("[T] are more strategically placed than their victims to absorb and distribute losses.").

184. CHAFEE, supra note 163, at 103-04.

185. Riesman, Fair Comment II, supra note 146, at 1309 n.114.

186. SAmANTHA BARBAS, LAWS OF IMAGE: PRIVACY AND Publicity IN AMERICA 105 (2015) [hereinafter BARBAS, LAWS OF IMAGE].

187. Riesman, Fair Comment I, supra note 150, at 1086.

188. Cross, supra note 130 , at 9. 
recognized the so-called "Kansas rule," extending a qualified privilege to false statements of fact concerning the conduct of a public official so long as there was probable cause to believe them to be true. ${ }^{189}$

Publishing advocates often phrased their arguments for liberalization in constitutional terms, and courts and legislatures that implemented more pressfriendly provisions justified them as protecting freedom of the press. ${ }^{190}$ Although the substantive law of libel changed little in the 1930s and '40s, the era saw significant developments in First Amendment law, and also in the public's attitudes towards free expression. Civil libertarian positions on freedom of expression began to emerge in the Supreme Court's First Amendment jurisprudence, as well as in the popular dialogue around freedom of speech. ${ }^{191}$ The Supreme Court "incorporated" the First Amendment, applying it to the states through the Fourteenth Amendment; it formalized constitutional protections against prior restraints and against various forms of content and viewpoint discrimination. ${ }^{192}$

Yet the Court did not address the constitutionality of libel laws, despite the explicit invitation to do so. In 1941, the Court granted certiorari in Schenectady Union Publishing Co. v. Sweeney. ${ }^{193}$ Congressman Martin Sweeney sued sixty-eight newspapers that ran a column by Drew Pearson alleging that Sweeney had sought to block a judicial candidate of the Roosevelt administration because he was Jewish. ${ }^{194}$ Morris Ernst, the newspaper's lawyer, laid the groundwork for New York Times $v$. Sullivan when he stated that strict libel laws, insofar as they inhibited the ability of citizens to criticize their leaders and to participate in democratic public discussion, raised issues "of constitutional dimension." 195 The Court declined to address the constitutional implications of libel law, affirming the Second Circuit's rejection of the newspaper's motion to dismiss without comment. ${ }^{196}$

189. Coleman v. MacLennan, 98 P. 281 (Kan. 1908); Rosenberg, The New Law, supra note 10, at 1161; LABUNSKI, supra note 17, at 58.

190. See, e.g., Public Criticism, Kingston Daily Freeman, June 1, 1935, at 4; Sweeney v. Patterson, 128 F.2d. 457, 458 ("Whatever is added to the field of libel is taken from the field of free debate.").

191. StePhen M. FeldMAn, Free Expression AND DEMOCRACY IN AMERICA 371-72 (2008); G. Edward White, The First Amendment Comes of Age: The Emergence of Free Speech in Twentieth Century America, 95 Mich. L. REV. 299, 331 (1996); Reuel E. Schiller, Free Speech and Expertise: Administrative Censorship and the Birth of the Modern First Amendment, 86 VA. L. REV. 1, 81 (2000).

192. Near v. Minnesota, 283 U.S. 697, 708-22 (1931); Thornhill v. Alabama, 310 U.S. 88, 102 (1940); Palko v. Connecticut, 302 U.S. 319, 327 (1937); De Jonge v. Oregon, 299 U.S. 353, 364-65 (1937); Stromberg v. California, 283 U.S. 359, 366-69 (1931); Martin v. Struthers, 319 U.S. 141 (1943); Lovell v. City of Griffin, 303 U.S. 444, 452 (1938).

193. 314 U.S. 605 (1941)

194. Schenectady Union Publ'g Co. v. Sweeney, 122 F.2d 288 (2d Cir. 1941), aff'd, 316 U.S. 642 (1942). 745).

195. Petitioner's Brief at 35, Schenectady Union Publ'g Co. v. Sweeney, 316 U.S. 642 (1942) (No.

196. See id. at 642 (majority opinion); Anderson, supra note 141, at 238 (“[T]he High Court would not receive another opportunity for 22 years to consider the constitutional limitations upon the power to award damages for libel of a public official."). 


\section{THE EQUILIBRIUM UPSET, 1945-1963}

In 1949, Harold Cross, libel lawyer for the New York Herald Tribune, former dean of the Columbia School of Journalism, and one of the most eminent libel authorities, spoke to press associations on the subject of "libel trends." There was a "long-term trend towards judicial and legislative liberality in the matter of defenses," he noted. ${ }^{197}$ Some legislatures and courts were "easing the law as to the existence of defenses with recognition of new ones." 198 In the past several years there had been a decrease in libel litigation, due to a "high sense of ethics" at newspapers; a growing number of "care and accuracy" programs" in newspaper offices; increased "libel consciousness" among journalists; and the decrease in "local crime, sensational and other kinds of 'libel-sensitive' news" during the war and its aftermath. ${ }^{199}$

At the same time, Cross spotted new trends on the horizon that were ominous for the press. Newspapers were returning to the coverage of local news, which brought with it the potential for libel claims. Cross predicted a trend towards an increase in libel suits resulting from the postwar Red Scare and bitter, often false accusations of Communist Party affiliation hurled by right-wing politicians at their opponents. ${ }^{200}$ Cross also observed the possibility of greater jury sympathy for libel plaintiffs and larger verdicts in libel cases, which he attributed to public animus towards the press as well as the "diminishing value of the dollar and the tendency toward a more openhanded distribution of wealth." 201

Cross's predictions were borne out in the 1950s and '60s, as publications faced an increase in libel suits and larger damage awards. Emboldened by significant libel judgments, plaintiff-friendly tort law trends, and growing public hostility towards the media, Americans from a variety of backgrounds were turning to libel law as a remedy for perceived injuries inflicted by the press. By the early 1960s, the press confronted a problem not unlike the "libel crisis" of eighty years earlier.

With their lawyers and systems for vetting and fact-checking, most publications were better equipped to deal with libel claims than in the past. Yet the internal structures for libel prevention and defense that the press had honed in previous decades were not adequate to deal with the new libel climate. Publishers were not prepared for more persistent and litigious plaintiffs, for juries that were unfriendly towards the press, or for the staggering amount of some damage awards - especially awards for punitive damages. They were also unprepared for the backlash that would ensue from investigative journalism and forthright press commentary on political and social affairs. By the time of New York Times v. Sullivan, libel had once again emerged as a major issue and dilemma for the press.

\footnotetext{
197. Cross, supra note 130 , at 8 .

198. Id.

199. Id. at 7.

200. Id.

201. Id. at 8 .
} 


\section{A. LiBel IN THE 1950S}

In the 1950s, there was a marked increase in libel cases against the press. ${ }^{202}$ At its 1953 meeting, the American Newspaper Publishers Association noted that libel claims against newspapers were on the rise. Arthur Hanson, counsel for the ANPA, claimed that the number of libel suits had grown by several hundred percent in the early 1950s. ${ }^{203}$ One professor claimed that the volume of libel cases in the 1950s was more than double that of any previous decade. ${ }^{204}$ "[T] he law of libel and slander has undergone a... revitalization, with a marked acceleration in the rate of institution of cases," observed an experienced trial lawyer. ${ }^{205}$ In the opinion of one newspaper publisher, "[m]ore and more lawyers are threatening by phone, letter, wire, or in person that if a given story is printed an action for libel will follow." 206 Publishers could no longer "disregard the threat of libel," wrote one lawyer. "A sufficient number of suits is brought to keep them on the alert. ... [T] he defense of such suits can cover so much ground that ... the investigation and legal costs can be burdensome. $" 207$

Not only were there more libel suits against the press, but the press seemed to be winning cases less often. One commentator observed that juries were demonstrating "vicarious satisfaction in helping a libel case plaintiff to the pot of gold at the end of the rainbow." ${ }^{208}$ A scholar who studied libel cases against the New Yorker noted that "[a]s the 1950s wore on, libel complaints against the magazine began to include demands for large damage awards." ${ }^{209}$ By the end of the decade, some libel plaintiffs were winning hundred-thousand-dollar verdicts. As famed plaintiffs' lawyer Melvin Belli observed in 1956, awards for libel sometimes exceeded the value of the most horrible personal injury cases: "A man's reputation is worth more before a jury than his limbs - even his life." 210 One columnist noted that juries were "grant[ing] such ridiculous sums for [libel] that newspaper owners [were] frightened and the reporters fear[ed] too." 211

202. In this era, "libel suits did become more of a concern, even for the largest publishers." See RosenberG, supra note 9, at 246. But see Lee Hills, Libel-Woe of the Weak, Bull. AM. SoC'Y NEWSPAPER EDS., Feb. 19, 1962, at 5 (noting lawyers who claim that the number of libel suits remained low).

203. ROSENBERG, supra note 9, at 247.

204. PEMBER, supra note 30, at 146-147; see also VERNON MILLER, SELECTED ESSAYS ON TORTS 191 n.2 (1960) (noting that the number of libel cases in the 1950s had been far "more numerous" than in previous years).

205. Francis Murnaghan, From Figment To Fiction To Philosophy-The Requirement of Proof of Damages in Libel Actions, 22 CATH. U. L. REV. 1, 4 (1972).

206. Hills, supra note 202, at 5.

207. Williams, supra note 125 , at 185 .

208. Murnaghan, supra note 205, at 4. This trend was especially evident when the defendant was a large newspaper-a corporation symbolizing "the forces which press on the average urban citizen and to which he ascribes many of his misfortunes." Id.

209. FORDE, supra note 114, at 113.

210. MELVin Belli, READY FOR THE PlaintifF 160 (1956).

211. George Sokolsky, A Daring Tribe, STAR PRESS, Jan. 30, 1959, at 6. 
One cause of this increase in libel litigation was the expanding volume of news media. In the 1950s, newspaper circulation reached historic highs. In 1950, 1,780 newspapers produced about 55 million copies daily, and by 1960, there were 1.3 newspapers per American. ${ }^{212}$ With increasing affluence and leisure time in the prosperous postwar era, the average American was devoting more time and money to media consumption. Americans in the 1950s spent about $\$ 18$ billion annually on recreational pursuits, including books, magazines, and newspapers. ${ }^{213}$

The increase in libel suits and judgments also reflected the expansion of tort litigation and liability more generally. Courts and legislatures in the 1950s created new torts and eroded barriers to recovery within existing causes of action. Tort litigation became big business; between 1950 and 1959, the amount paid into the tort system grew from $\$ 1.8$ billion to $\$ 5.4$ billion. ${ }^{214}$ By the end of the decade, personal injury litigation had become a specialty of plaintiffs' lawyers, and the personal injury bar emerged as a distinct segment of the profession. ${ }^{215}$ The volume of tort lawsuits increased substantially in the 1950s and the average tort award tripled in size. ${ }^{216}$ In particular, there was a trend towards more liberal compensation for intangible injuries such as emotional distress and pain and suffering. ${ }^{217}$ There was a "growing sense of entitlement to security," one torts scholar observed-a feeling that people deserved to be compensated fully for their injuries. ${ }^{218}$

Americans were becoming more protective of their public images and reputations, which affected the libel climate as well. The right to sue and recover damages for reputational harm assumed more salience in an era when popular culture and mass media encouraged individuals to devote their energies to cultivating favorable public images. ${ }^{219}$ Harold Cross speculated that politicians in particular were becoming especially conscious of their public images, which had become critical assets in an age of televised campaigns. ${ }^{220}$ In the hostile political culture spawned by the Cold War, with smear attacks and accusations of communism, there was "judicial and public unhappiness with what [were] regarded as excesses of freedom of comment" and the damaging effects of those excesses on people's reputations. ${ }^{221}$ Liberal intellectuals who usually would have supported extensions of free speech protections

212. William H. Young, THE 1950S, at 153 (2004).

213. DaVid E. Sumner, The Magazine Century: American Magazines Since 1900, at 117 (2010).

214. JOHN FABIAN WitT, PATRIOTS AND COSMOPOLITANS: HidDEN HiSTORIES OF AMERICAN LAW 245 (2007).

215. KenNeth S. Abraham, The Liability Century: Insurance and Tort LaW From the PROGRESSIVE ERA TO 9/11, at 83-85 (2008).

216. Jed HANDElsman Shugerman, The PeOPle's Courts: PuRsuing JUdicial INDEPENDENCE IN AMERICA 243 (2012).

217. Philip Merkel, Pain and Suffering Damages at Mid-Twentieth Century: A Retrospective View of the Problem and the Legal Academy's First Responses, 34 CAP. U. L. REV. 545, 559 (2006).

218. Louis L. Jaffe, Damages for Personal Injury: The Impact of Insurance, 18 LAW \& CONTEMP. PROBS. 219, 222 (1953).

219. See generally BARBAS, LAWS OF IMAGE, supra note 186.

220. Cross, supra note 130, at 7-8.

221. Samuel Krislov, Mr. Justice Black Reopens the Free Speech Debate, 11 UCLA L. ReV. 189, $210(1963)$. 
for the press worried more about issues of reputation and consequently viewed libel actions as an important remedy against political character assassination. ${ }^{222}$ Some liberal commentators advocated strengthening libel law to make it easier to recover for defamatory smears by right-wing critics. ${ }^{223}$ Sensitivity to reputation, and the fragility of reputation, may also have been responsible for greater judicial severity in determining what constituted defamation. ${ }^{224}$ Courts rejected defendants' motions to dismiss libel complaints on the grounds that the allegations were not defamatory; the meanings of challenged statements were increasingly put to juries. ${ }^{225}$

More forthright political and social commentary in newspapers also provoked libel claims. The politicized environment yielded more press coverage of "politicalideological" subjects such as anticommunism, which spawned libel suits, according to Harold Cross. ${ }^{226}$ Acerbic political columnists like Drew Pearson, Walter Winchell, and Westbrook Pegler inflamed tempers and "set in motion a ... fashion to sue."227 In 1954, a federal jury ordered right-wing columnist Pegler to pay libel damages totaling \$175,001 to writer Quentin Reynolds over personal slurs Pegler leveled against Reynolds in his columns. Actual damages were $\$ 1$ and punitive damages $\$ 175,000 .{ }^{228}$ "Never in the history of libel actions had a complaint that warranted award of only $\$ 1$ for actual damages ... produced so large an award of punitive damages," observed one commentator on the case. ${ }^{229}$

Changing dynamics between the press and the government also contributed to the rise in libel litigation. ${ }^{230}$ As a result of the government suppression of speech and political expression during the Red Scare, there was increasing suspicion among journalists of the credibility of official news sources and less willingness to rely on those sources. ${ }^{231}$ The foundations were being established for the more adversarial stance between the government and the press that would define their relationship over the next decade. Libel suits were also triggered by the rise of investigative journalism at large, well-funded newspapers. ${ }^{232}$ As television news coverage began to turn a spotlight on social problems, ${ }^{233}$ newspaper publishers saw investigative journalism and more frank reporting on issues such as social inequality and civil rights as a way to counter competition from broadcast media. ${ }^{234}$ Politicians and public officials retaliated against exposure of their misconduct with claims for libel.

222. Rosenberg, Distorted Shape, supra note 10, at 49.

223. Id.

224. Cross, supra note 130, at 7-8. See also Leon Yankwich, The Protection of Newspaper Comment on Public Men and Public Matters, 11 LA. L. REV. 327, 331 (1950).

225. Cross, supra note 130, at 9 (noting a tendency of the courts "to construe the meaning of the published matter strictly against the publisher and let him justify as best he may what he has printed.").

226. Id. at 7 .

227. Id. at 8 .

228. Reynolds v. Pegler, 123 F. Supp. 36, 37 (S.D.N.Y. 1954).

229. W.B. Dickinson Jr., Libel Suits and Press Freedom, ED. RSCH. REPS. (Dec. 4, 1963).

230. Id. at 51 .

231. Id.

232. See James L. AuCoIn, The Evolution of AMERICAN InVESTIGATIVE Journalism (2005).

233. Id at 11 .

234. ROSENBERG, supra note 9 , at 246. 
A final factor contributing to the "libel crisis" was public distrust of the press. "Across the land, citizens [were] fretful about the performance of the mass media of communication," the Christian Century observed in $1959 .{ }^{235}$ The 1950s were an era of moral conservatism. The decade saw "purity movements," including campaigns for government censorship of literature, media, and popular culture. The press was attacked for its sensationalism, particularly its depictions of trials and crimes; in 1952, a national study found "widespread criticism and disapproval" of newspapers for their alleged sensationalism and bias. ${ }^{236}$ By 1951, books, radio, television, magazines, and newspapers were "all feeling increasing pressure from advocates of censorship." 237 Lawmaking bodies were "passing censorship laws so fast that it [was] difficult to make an accurate count." ${ }^{238}$ The majority of respondents in one poll thought that "the press should be subjected to some kind of control," including licensing by the federal government. ${ }^{239}$ One critic suggested that the "government hold newspapers responsible civilly or criminally for...f false or unqualified statements of fact or half-truths." ${ }^{240}$

These anti-press sentiments were reflected in libel laws. Several state legislatures passed substantive and jurisdictional laws that made it easier for plaintiffs to recover against the press in libel cases. ${ }^{241}$ In 1956, the Georgia legislature passed a law that made newspaper publishing corporations subject to libel suits in any of the state's counties where the paper had a circulation of fifty or more copies. ${ }^{242} \mathrm{~A}$ law that would have made publishing libel a criminal offense punishable by heavy fines and jail sentences was passed by the Rhode Island legislature but vetoed by the governor in $1956{ }^{243}$ By the early 1960s, more "stringent application of libel laws" had become socially accepted. ${ }^{244}$

\section{B. The New Libel Crisis}

The press was beginning to feel the heat. The demand for libel insurance was on the rise, and premiums were increasing. ${ }^{245}$ There were reports of some publications having their policies terminated because of "excessive judgments awarded by juries

235. Theodore Peterson, A Criticism of Press Criticism, Christian Century, Sept. 16, 1959, at 1048.

236. Criticism of Press is Seen in Survey, N.Y. TimES, May 14, 1952, at 23.

237. Murray Schumach, Censorship Fight Waged on a Nation-Wide Front, N.Y. TimES, Nov. 1, 1953 , at E7.

238. Lewis C. Smith, The Truth Beaten Down, 4 Coll. Composition \& COMMC'N 138, 139 (1953).

239. J.A. Thalheimer \& J.R. Gerberich, Reader Attitudes Toward Questions of Newspaper Policy and Practice, 12 Journalism Q. 266, 269 (1935).

240. Eustace Cullinan, The Rights of Newspapers: May They Print Whatever They Choose?, 41 ABA J. 1020, 1023 (1955).

241. Georgia Libel Bill on Press Is Passed, N.Y. TIMES, Feb. 2, 1956, at 17.

242. Threatening the Press, CORPuS Christi CALLER TIMES, Feb. 19, 1956, at 10.

243. James Whelan, R.I. Bill To Jail for Libel Draws Protest from the Press, BERKSHIRE EAGLE, May 3, 1956, at 19.

244. Krislov, supra note 221, at 210 .

245. Libel Insurance, BUS. WK., Jun. 8, 1946, at 61. 
in [libel] suits." ${ }^{246}$ As the executive editor of the Knight newspapers described his view of the situation, there was an alarming rise in efforts by plaintiffs' lawyers, in a "litigious-minded" society, to "dragoon publishers into a settlement payoff."247

Publications worked to shore up their libel prevention and defense systems. Newspapers that had not previously used prepublication review began to commission lawyers for libel vetting. ${ }^{248}$ The threat of libel suits alarmed editors at the New Yorker, according to a historian of the magazine. ${ }^{249}$ Editor Harold Ross hired an additional lawyer to screen all articles. ${ }^{250}$ Lawyers for the New York Times began closely monitoring the libel situation at the paper, frequently drafting memoranda on the status of libel suits against the Times, often in response to requests from the publisher. ${ }^{251}$

As in tort cases more generally, damage awards in libel cases had risen exponentially over the decade, ${ }^{252}$ displaying a "nationwide trend towards huge awards in negligence and libel." 253 "[D]amage suit lawyers are looking on newspaper libel as a new field for large judgments," one editor noted. ${ }^{254}$ "It is plain that libel claimants are beginning to shoot for the moon," observed Northwestern University law professor Willard H. Pedrick. ${ }^{255}$ Reporter Martin Gansberg of the New York Times blamed large damage awards in libel cases on television and "the bugaboo called inflation." 256 While television spread news about press wrongdoings to an unprecedented audience, inflation encouraged "juries to award fantastic sums of money to those who have been wronged." ${ }^{257}$ Exorbitant awards in libel cases, wrote Editor \& Publisher, threatened to "become the twentieth century method of silencing the press." 258 One journalist warned that "[i]f large damages are allowed, freedom of the press will be curbed because publications would be unable to survive

246. William Clark, Libel Segment of Insurance Industry Small but Colorful, CHI. TRIB., Nov. 21, 1951 , at 61 .

247. Hills, supra note 202, at 5-6.

248. BonNie BrenNen, For the Record: An Oral History of Rochester, New York NEWSWORKERS 111 (2001).

249. FORDE, supra note 114, at 117-18.

250. Id. at 118 .

251. See documents contained in ARThUR Hays Sulzberger PaPers (on file with New York Public Library, Manuscripts and Archives Division, Box 196, Folder 17).

252. ROSENBERG, supra note 9 , at 247.

253. Martin Gansberg, Big Award in Suit Follows Trend, N.Y. TimES, Feb. 25, 1964, at 61.

254. Hills, supra note 202, at 5.

255. Willard Pedrick, Freedom of the Press and The Law of Libel: The Modern Revised Translation, 49 CORNELL L. Q. 581, 582 n.2 (1963).

256. Martin Gansberg, Introduction, in CHARLES ANGOFF, THE BOOK OF LIBEL 1 (1966) [hereinafter Gansberg, Introduction]. See also Hills, supra note 202, at 5 ("The problem is intensified because run-away juries in personal injury cases have gone far beyond reason in their anxiety to keep abreast of inflation.").

257. Gansberg, Introduction, supra note 256, at 1 (Juries had "lost track of the value of money in this inflationary age of ours. Men and women dream green; they are unrealistic when they make awards in libel cases.").

258. The New Silencer, ED. \& PUBLiSHER, Nov. 16, 1963, at 6. 
big awards."259 In some cases, libel judgments were so high that they threatened bankruptcy for some newspapers. ${ }^{260}$

Unprecedented punitive damage awards created a panic in publishing circles. ${ }^{261}$ In 1962, John Henry Faulk, a popular radio host and outspoken civil libertarian, filed suit against AWARE, Inc., a right-wing group that blacklisted entertainment stars for alleged pro-communist sympathies. He won a $\$ 3.5$ million jury verdict, which included \$2.5 million in punitive damages. Faulk actually received more than he asked for. The trial judge refused to set aside the jury's award, writing that "[ $[$ this unprecedented award was evidently intended to express the conscience of the community... concerning a matter of fundamental rights deemed of great importance to the general public and the country."262

The Faulk decision was followed in 1963 by a verdict of $\$ 3,060,000$ awarded by an Atlanta jury to former University of Georgia athletic director Wally Butts in a libel suit he brought against Curtis Publishing Company, publishers of the Saturday Evening Post. ${ }^{263}$ Butts sued for $\$ 5$ million in general damages and $\$ 5$ million in punitive damages. The allegedly libelous article accused Butts of fixing a college football game. ${ }^{264}$ It took a jury only an hour to find for Butts and award him $\$ 60,000$ in actual damages and $\$ 3$ million in punitive damages. One juror disclosed that some of his colleagues had wanted to award even more than the $\$ 5$ million in punitive damages sought by the plaintiff, because they felt that the Post article showed "terrible carelessness in preparation" and was "full of inaccuracies." 265

Following the Butts decision, in a parallel to the conduct of the press in the late nineteenth century, newspaper editorial pages denounced frivolous claims, purportedly hyper-sensitive plaintiffs, and excessive judgments in libel cases. Publishers believed that the implications of the Butts verdict were ominous. Because of the publicity given the case and the size of the award, they feared an increase in the number of suits and a rise in libel insurance rates. ${ }^{266}$ Libel lawyer Morris Ernst denounced large punitive damage awards in libel cases as a "new technique[] . . to imperil freedom."267 However important personal restitution for reputational harm,

259. Gansberg, supra note 253, at 61 .

260. Id. In a December 1956 editorial entitled "Bigger Libel Suits," an Oregon newspaper complained that another paper in the state was "on the defending end of how many million dollars worth it probably doesn't know" of libel lawsuits. Other Editors Comment, AlBANy DemOCRAT HeRALD, Jan. 1,1957 , at 4 .

261. The trend towards punitive damages in libel cases was part of a broader trend, as American courts, spurred by the consumer movement, began to award punitive damages more frequently in cases outside of intentional torts. Skyler M. Sanders, Uncle Sam and the Partitioning Punitive Problem: A Federal Split-Recovery Statute or a Federal Tax?, 40 PEPP. L. REV. 785, 793 (2013).

262. Faulk v. Aware, Inc., 231 N.Y.S.2d 270, 280 (N.Y. Sup. Ct. 1962).

263. Butts v. Curtis Publ'g Co., 225 F. Supp. 916 (N.D. Ga. 1964).

264. Dickinson, supra note 229.

265. Id.

266. High Cost of Libel, NewsweEK, Sept. 2, 1963, at 72.

267. Morris Ernst, A Danger in Big Libel Awards, St. Louis Post-DisPatch, Sept. 1, 1963, at 20. 
it was not important enough that plaintiffs be compensated in sums that imperil the "very existence of [the] mass media." 268

Ernst believed that if the Butts award were sustained, its magnitude would put an "embargo ... on the national flow of ideas." ${ }^{269}$ Not since the right of public authorities to suppress press criticism was repudiated in the 1735 libel trial of John Peter Zenger "ha[d] an instrument been developed so dangerous to a free market place of thought as unrestricted punitive damages." ${ }^{270}$ Editor and Publisher warned that, if the awards like Butts were allowed to stand, they would act as a dangerous restraint on reporting material in the public interest. ${ }^{271}$ Even though the award was later reduced to $\$ 460,000$, it contributed to the demise of the Saturday Evening Post, which shut its doors in $1969 .{ }^{272}$

\section{NEW YoRK TIMES V. SULLIVAN}

It was in this context that New York Times v. Sullivan made its way through the courts. On March 29, 1960, the Times ran an ad titled "Heed Their Rising Voices," signed by more than twenty leaders of the civil rights movement. ${ }^{273}$ The ad described alleged police brutality against civil rights protestors at Alabama State College in Montgomery. ${ }^{274}$ Five local and state officials, including Montgomery city commissioner L.B. Sullivan, filed separate defamation actions in Alabama state court against the Times, seeking a total of over $\$ 3$ million in damages. ${ }^{275}$ Even though Sullivan did not suffer any ostensible reputational damage, and there were only trivial factual errors in the advertisement, Sullivan won a jury verdict of $\$ 500,000$, consisting of both compensatory and punitive damages, which was upheld by the Alabama Supreme Court in 1962. ${ }^{276}$ The Times was also sued for \$3 million for an article by reporter Harrison Salisbury titled "Fear and Hatred Grip Birmingham," which blamed local authorities for terrorizing civil rights activists. ${ }^{277}$ The suits against the Times were part of a broader attack by Southern authorities on the Northern news media - an obvious attempt to use large libel judgments as a way to

268. Id. "The First Amendment to the Constitution ... forbids the abridging of freedom of the press. But why guarantee this freedom. ... if a newspaper can be put out of business by libel verdicts that are in fantastic disproportion to the total assets of the newspaper?" asked the St. Louis Post-Dispatch in an editorial. Libel in Arkansas, St. Louis Post-DisPatch, Nov. 25, 1963, at 16.

269. Danger Seen in Size of Libel Award, PHX. ARIZ. RepuBLIC, Aug. 23, 1963, at 16.

270. Id.

271. Dickinson, supra note 229 (quoting Edwin Roth, Britain's Libel Laws Keep Profumo Case Under Cover, ED. \& PUBLISHER, June 15, 1963, at 11).

272. Gordon S. White, Wally Butts, Ex-Georgia Coach, Dies: Won Large Libel Suit, N.Y. TIMES, Dec. 18,1973 , at 46 .

273. N.Y. Times Co. v. Sullivan, 376 U.S. 254, 256-57 (1964).

274. Id. at $257-58$.

275. Ottley et al., supra note 3, at 748 n.39.

276. Sullivan, 376 U.S. at 256.

277. See Ottley et al., supra note 3, at 745-47. For the article in question, see Harrison E. Salisbury, Fear and Hatred Grip Birmingham, N.Y. TimES, Apr. 12, 1960, at 1. See also Memorandum to Harding F. Bancroft, Esq. Re: New York Times litigation, Dec. 2, 1960, in ARTHUR HAYS SUlzBERGER PAPERS, supra note 251 . 
intimidate news outlets and deter them from covering the civil rights movement. ${ }^{278}$ By 1964, there were seventeen libel actions pending in the South against the New York Times, the Saturday Evening Post, CBS, and The Associated Press, among other news outlets, seeking a total of \$288 million in damages. ${ }^{279}$ The Times withdrew its reporters from Alabama because of the libel suits. ${ }^{280}$ According to James Goodale, later general counsel of the Times, had the U.S. Supreme Court not decided in favor of the paper in the Sullivan case, "there was a reasonable question of whether the Times, then wracked by strikes and small profits, could survive."281

The New York Times appealed the Sullivan verdict to the Supreme Court. Its brief undertook a constitutional analysis of libel, arguing that strict liability in libel cases involving criticism of public officials effectively constituted "seditious libel," the crime of criticizing the government, long deemed to be unconstitutional. ${ }^{282}$ The case became a cause célèbre in media circles; newspapers across the country rallied for the Times. Editorials described the Alabama suits as part of the trend of high-stakes libel litigation and punitive judgments. The Alabama lawsuits were another example of "abuses of the libel weapon" intended to "penalize freedom of expression" through "astronomical verdicts" intended to induce "the risk of bankruptcy," wrote one editorial. $^{283}$ The Court granted certiorari in $1963 .^{284}$

The Supreme Court under Earl Warren, noted for its efforts on behalf of civil rights, took the case in part due to its obvious implications for the civil rights movement. $^{285}$ Members of the Court were also interested in First Amendment issues. $^{286}$ Justice Hugo Black, a First Amendment "absolutist," had publicly expressed his belief that any infringement on speech, including libel actions, was unconstitutional. $^{287}$ First Amendment jurisprudence had developed since the last time the Court was asked to consider libel, and the expanding body of case law pointed in the direction of more extensive liberties for speakers, including the press. $^{288}$ The Court was also motivated to take the Sullivan case by the increasing

278. Ottley et al., supra note 3, at 747.

279. John Herbers, Libel Actions Ask Millions in South: 17 Suits by Public Officials are Pending in Courts, N.Y. TIMES, Apr. 4, 1964, at 12.

280. LEWIS, supra note 3 , at 43 .

281. Id. at 35 .

282. Brief for Petitioner at 41-51, N.Y. Times Co.. v. Sullivan, 376 U.S. 254 (No. 39), 1963 WL 105891.

283. Libel and the 1st Amendment, CHI. TRIB., Oct. 20, 1962, at 14.

284. N.Y. Times Co. v. Sullivan, 371 U.S. 946 (1963).

285. On the Warren Court and the civil rights movement, see MORTON J. HORWITZ, THE WARREN COURT AND THE PURSUIT OF JUSTICE 32-37 (1998).

286. On Justice Black and the First Amendment, see Krislov, supra note 221; on Justice Brennan, see Geoffrey Stone, Justice Brennan and the Freedom of Speech: A First Amendment Odyssey, 139 U. PA. L. REV. 1333 (1991); on Douglas, see Thomas Emerson, Justice Douglas' Contribution to the Law: The First Amendment, 74 COLUM. L. REV. 353 (1974).

287. Justice Black and First Amendment Absolutes: A Public Interview, 37 N.Y.U. L. REV. 549, 557 (1962) ("I have no doubt myself that the [First Amendment freedom of speech] provision, as written and adopted, intended that there should be no libel or defamation law in the United States under the United States Government, just absolutely none so far as I am concerned.").

288. HORWITZ, supra note 285, at 38; see also Nadine Strossen, Freedom of Speech in the Warren Court 71-72, in THE WARREN COURT: A RETROSPECTIVE (Bernard Schwartz ed., 1996). 
vulnerability of the press in the face of libel suits. In these new litigation and cultural climates, publications could no longer depend on their established systems to shield them from libel liability; freedom of the press demanded more legal protection.

Both the Times and its supporters, and the Supreme Court in its opinion in Sullivan, referenced the current libel wars in their arguments. ${ }^{289}$ In its brief, the Times noted "the risk of enormous punitive awards by hostile juries." 290 The Chicago Tribune, in an amicus brief, invoked the specter of "unlimited actual and punitive damages" putting "publisher[s] permanently . . out of business." ${ }^{.291}$ In his concurring opinion, Justice Goldberg described the recent trend of public officials attempting to suppress criticism by "resort[ing] to friendly juries." 292 In the majority opinion, Justice Brennan noted that a "succession" of large judgments could imperil a publication's very existence and cast a "pall of fear and timidity" over critical reporting. ${ }^{293}$ Justice Black, also concurring, wrote that if the $\$ 500,000$ judgment were upheld, it would "threaten the very existence of an American press," stating further that there was "no reason to believe that there are not more such huge verdicts lurking around the corner for the Times or any other newspaper or broadcaster."294 He also noted that newspapers had become "easy prey for libel verdict seekers." 295 When the decision was issued in March 1964, newspapers heralded it as offering relief from the "recent history of damage actions" in which juries and public figures appeared to cooperate in "schemes of legal retribution." 296 The Detroit Free Press announced that Sullivan would put an end to the trend of "intent to intimidate" that had been the source of an increasing number of libel suits, and that it would stop "[t]he five and six figure libel-claim gimmick."297

New York Times $v$. Sullivan was a product of its time, as scholars have noted. ${ }^{298}$ It grew out of the political and cultural environment of the early 1960s; it was also a product of the libel climate. The breakdown of the press's longstanding truce with libel, and the near-existential threats caused by libel suits at publications like the New York Times, highlighted the need for greater protections for the press. Sullivan was the culmination of a nearly 100 -year history in which the press had struggled with and learned to live with libel, only to see that equilibrium upset in the 1950s. The Court intervened in the state law of libel, in part to provide "breathing room" for the

\footnotetext{
289. N.Y. Times Co. v. Sullivan, 376 U.S. 254, 272 (1964).

290. Brief for Petitioner at 90, N.Y. Times Co. v. Sullivan, 376 U.S. 254 (1964) (No. 39), 1963 WL 105891 .

291. Brief of Tribune Company as Amicus Curiae at 7, N.Y. Times Co. v. Sullivan, 376 U.S. 254 (1964) (No. 39), 1963 WL 105890.

292. Sullivan, 376 U.S. at 304 (Goldberg, J., concurring).

293. Id. at 278 (majority opinion).

294. Id. at 294-95 (Black, J., concurring).

295. Id. at 295.

296. Right of Criticism Upheld, PORTSMOUTH Herald, Mar. 20, 1964, at 4.

297. Royce Rowles, High Court Curb on Libel Helps John Q. as Well, Detroit Free PrEss, Mar. 16,1964 , at 6.

298. See supra notes 3-9.
} 
press that could no longer be attained under the existing legal doctrines as they operated in polarized and increasingly unstable social and legal environments.

\section{CONCLUSION}

By the time of Sullivan, the press had traveled a long way with libel. For over two centuries, it had worked to coexist with libel doctrines that were, on their face, favorable towards plaintiffs. Faced with a growing number of libel suits in the late nineteenth century, the press developed strategies to avoid and defeat libel suits, including the construction of sophisticated editing and vetting systems, and relying on the advantages of the press in libel litigation, including the press's status as a repeat player in libel lawsuits, and the tendency of plaintiffs to jettison claims, especially when confronted with threats of negative publicity. Through this system, publishers achieved significant latitude to publish despite libel law's stringencies.

Social, cultural, and political developments in the $1950 \mathrm{~s}$ - a more plaintifffriendly tort law climate, public hostility towards the press, and American culture's growing protectiveness of reputational rights - led to strains on the press's system of libel protection. As publishers confronted increasing numbers of libel suits, more persistent plaintiffs, and unfavorable outcomes in libel cases, including large damage awards, it was apparent that the press could no longer rely on its established protocols as a barrier against libel liability. The upset of the equilibrium between libel law and press freedom that had been attained in earlier decades spurred critics, publishers, and the Supreme Court to become concerned with the effects of libel on freedom of publishing. New York Times v. Sullivan arose in this context.

Sullivan reversed the libel crisis. As has been well-documented, Sullivan's actual malice standard extended unprecedented latitude to the press to report and comment on public officials. In the 1960s and '70s, the Court extended the Sullivan rule to cover statements about public figures, further broadening the freedom of the press to report on newsworthy matters and individuals. ${ }^{299}$ The constitutional safeguards offered by Sullivan and its progeny rendered libel law a much "less pervasive influence in the newsroom," in the words of scholar David Anderson. ${ }^{300}$ New York Times v. Sullivan initiated a new chapter in the history of the press's relationship to libel law, a chapter characterized by expansive freedoms, and one that is still being written.

This Article has aimed to illustrate the importance of contexts in the study of media law and First Amendment law. "Freedom of the press" is not only a legal concept; to understand press freedom, scholars must examine the practical workings of that freedom, as lived out in the real-world decisions and experiences of publishers, journalists, and their audiences. In documenting the history of the relationship of the press to libel law prior to Sullivan, and the libel climate from which the Sullivan decision emerged, this work has hopefully contributed to that project.

299. See, e.g., Gertz v. Robert Welch, Inc., 418 U.S. 323 (1974); see also Curtis Publ'g Co. v. Butts, 388 U.S. 130 (1967).

300. See David A. Anderson, Libel and Press Self-Censorship, 53 TEX. L. REV. 422, 430 (1975). 